\title{
ON THE LEAF DEVELOPMENT IN PALAEOZOIC MOSSES OF THE ORDER PROTOSPHAGNALES
}

\author{
О РАЗВИТИИ ЛИСТА У ПАЛЕОЗОЙСКИХ МХОВ ПОРЯДКА РRОТОSPHAGNALES \\ ELENA V. MASLOVA ${ }^{1,4}$, YULIYA V. MOSSEICHIK ${ }^{2}$, IGOR A. IGNATIEV ${ }^{2}$, \\ OLEG V. IVANOV ${ }^{3} \&$ MiCHAEL S. IGNATOV ${ }^{4}$ \\ ЕЛЕНА В. МАСЛОВА ${ }^{1,4}$, ЮЛИЯ В. МОСЕЙЧИК ${ }^{2}$, ИГОРЬ А. ИГНАТЬЕВ ${ }^{2}$, \\ ОЛЕГ В. ИВАНОВ ${ }^{3}$, МИХАИЛ С. ИГНАТОВ $^{4}$
}

Abstract

Upper Palaeozoic mosses of the order Protosphagnales are studied for their leaf development and found to be quite different from modern mosses. In the latter, the small actively dividing cells occur at latest stages of leaf development in the proximal part of leaf, whereas in Protosphagnales cell divisions may continue in the subapical part of leaf. Also, zones of small cells occur in some genera in the median part of the leaf, indicating relatively independent development of different leaf parts. The narrow insertion of leaves, which consists almost entirely of the costa, makes easier late growth of the basal leaf portion, where expanded aurucules may form. The small cells in median part of leaf differentiate both acropetally and basipetally, but cells above this zone become dimorphous more often than below it. The pattern of cell dimorphism is correlated with shifts of cell rows during leaf development.

Резюме

Для верхнепалеозойских мхов порядка Protosphagnales изучены листья и их фрагменты, представляющие разные стадии их развития. Анализ порядка дифференциации клеток в разных частях листа показывает существенные отличия Protosphagnales от современных мхов. У последних мелкие активно делящиеся клетки обнаруживаются практически всегда только в основании листа, тогда как у палеозойских мхов порядка Protosphagnales деления могут долго продолжаться близ верхушки листа. Кроме того, зоны с мелкими недавно поделившимися клетками обнаруживаются в средней части листа, указывая на относительно независимое развитие отдельных его частей. Узкое прикрепление листа к стеблю, охватывающее практически только жилку, делает возможным позднее дополнительное развитие ушковидного основания. Мелкие клетки средней части листа дифференцируются как акропетально, так и базипетально, но выше этой зоны диморфизм клеток формируется более выраженно. Показана обусловленность клеточного диморфизма сдвигами клеточных рядов друг относительно друга.

KEYWORDS: cell divisions, fossils, morphogenesis, leaf, Bryophyta, Palaeozoic, Permian, Protosphagnales

\section{INTRODUCTION}

Fossil moss history is a relatively poorly known field of paleobotany. In general, a larger part of collections from Coenosoic deposits, including Eocenic/Oligocenic amber, were referred to modern species (Miller, 1983; Frahm, 2010; Ignatov \& Perkovky, 2011). Other Tertuary collections were described as separate species of extant genera, while most of Mesozoic and part of Palaeozoic fossil mosses were referred to separate genera (Neuburg, 1960; Krassilov, 1973; Ignatov, 1990, 1992; Ignatov \& Shcherbakov, 2007,2009, etc.). These extinct genera were left mostly as insertae sedis plants, as their placement in any contempo- rary group would be too poorly based due to incompleteness of material and lack of characters known in modern groups. Most of them could be placed to several modern families with equal probability.

There is only one taxon of suprageneric level in fossil mosses: this is the order Protosphagnales of the Sphagnopsida. Its representatives are known only in the fossil state, being common in the uppermost Lower Permian and throughout Upper Permian of Angaraland (Kuznetsk, Tunguska and Pechora Coal Basins) and adjacent areas of the Subangaraland in the Russian Platform (Ignatov, 1990). Other Subangaraland territories, now rep-

1 - Belgorod State University, Pobedy square, 85, Belgorod, 308015 Russia - Россия 308015, Белгород, пл. Победы, 85, Белгородский государственный университет; e-mail: e maslova@list.ru

2 - Geological Institute of the Russ. Acad. Sci., Pyzhevsky, $\overline{7}$, Moscow, 119017, Russia - Россия 119017, Москва, Пыжевский пер., 7, Геологический институт РАH; e-mails: mosseichik@ginras.ru \& ignatievia@gimras.ru

3 - P.N. Lebedev' Institue of Physics of Russ. Acad. Sci., Leninsky 53, Moscow 119991 Russia - Россия 119991, Москва, Ленинский проспект, 53, ФИАН; e-mail: ivanov@td.lpi.ru

4 - Main Botanical Garden of the Russ. Acad. Sci., Botanicheskaya 4, Moscow, 127276 Russia - Россия 127276, Москва, Ботаническая, 4, Главный ботанический сад РAH; e-mail: misha_ignatov@list.ru 

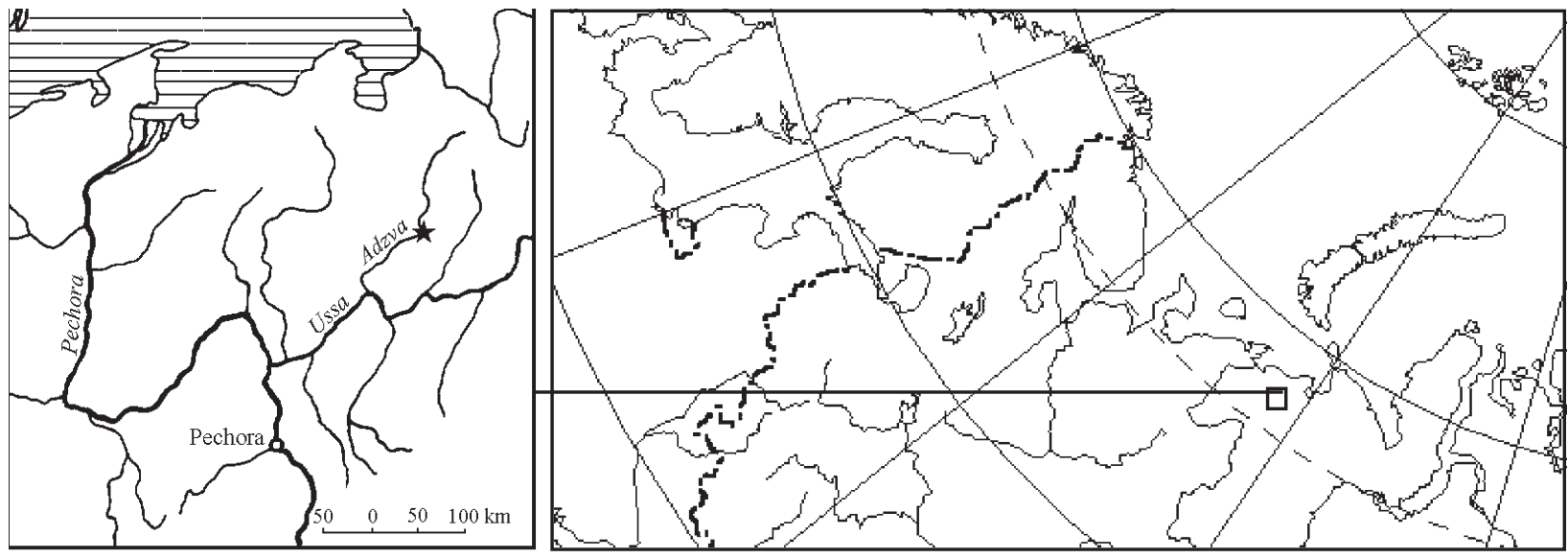

Fig. 1. Collecting locality of fossil material of Protosphagnales (star).

resenting Russian Far East and NW China, also brought records which may be referred to the genera placed here in Protosphagnales (Wu et al., 2000; Meyen, 1982).

The order Protosphagnales and three genera originally referred to it were described by Neuburg (1960). These genera, Protosphagnum, Junjagia and Vorcutannularia, are characterized by the peculiar differentiation of leaf lamina cells, so the darker cells forming net and lighter cells situated in loops of this net, are reminiscent of modern Sphagnum. In addition to the Protosphagnalean genera, Neuburg described 6 genera which she classified in the Bryopsida without more exact placement.

Abramov \& Savicz-Lyubitskaya (1963) suggested to place Intia, one of the genera described by Neuburg, in the Mniaceae, due to overall similarity in size, leaf shape, border, and areolation pattern. The leaf shape and size, distinct leaf border and the leaf variation patterns in Palaeozoic mosses are quite similar to those in modern Mniaceae.

At the same time, Fefilova (1978) and Ignatov (1990) noted that Protosphagnum and Intia have too many transitional morphotypes and are apparently closely related. These transitions were noted also in the original discussion by Neuburg (1960), but she interpreted this as an evidence of the origin of Protosphagnales from an Intialike ancestor, preferring to keep them in different orders.

Further evaluation of the systematic position of Protosphagnum and related genera is quite intriguing and important for understanding moss evolution in Upper Permian, 270-251 Ma ago. For this purpose, in 2009 we undertook an expedition which provided new material of fine preservation, suitable for study with the bulk maceration method.

\section{ORIGIN OF MATERIAL}

The material for the present study was collected from the Pechora Coal Basin, Adzva River left bank, ca. 90 $\mathrm{km}$ upstream from the mouth (Fig. 1), outcrop No. 32 of A.A. Chernov, layers 197-199. Numbering of layers follows Pukhonto (1998).

The plant-bearing deposits consist of green-gray finegrained loamy siltstones and mudstones containing thin lenses of coal. According to Pukhonto (1998) and identifications of I.A. Ignatiev, along with the mosses cordaitanthaleans are buried : Cordaites candalepensis (Zal.) S.Meyen, Cordaites clercii Zal., Rufloria sp.; cardiolepidians: Phylladoderma arberi Zal., Permotheca sp., Cardiolepis piniformis Neub., Tundrodendron petschorense Zal.; supposed peltasperms: Pursongia paimboica Pukh., Lopadiangium sp., Sporophyllithes sp.; dispersal seeds of Bardocarpus superus Neub., various Zamiopteris and some other plant megafossils.

This plant assemblage is typical for the upper part of Talbeiskaya suite of the Pechora series. The age of the deposits has been determined as Upper Kazanian of the Upper Permian of East European (continental) scale (Menning et al., 2006).

The studied plant burials were probably formed under conditions of the low, partly waterlogged flood plain. The moss remains occur in the form of mass accumulations gathered together on the bottom of flat hollows, oxbow lakes and pools, which become covered with finegrained deposits during the floods.

The transportation of plant remains was presumably short, i.e. the burials are hypoautochtonous. It is evident from: a) the morphological integrity of plant remains, including the preservation of moss leafy shoot fragments; $b$ ) the absence of unilateral orientation of plant remains, as well as c) the absence of traces of their differential sorting.

Reconstructions of parent flood-plain vegetation (Ignatiev \& Ignatiev, 2001) show the existence of two main types of forest-shrub communities: a) the cordaitean forests occupied the more disturbed sites of fluvial plain; b) Phylladoderma shrubs on the hydrodynamically more stable waterlogged sites of living flood plain. Judging from recurring association of the moss remains with Phylladoderma leaf fragments, the mosses preferred the same waterlogged sites, where soils, as evidenced the buried palaeosoil profiles, were quite often poor in organic matter.

\section{PURPOSE OF THE PRESENT STUDY}

Our main project on the taxonomy of the Protosphagnales will obviously take considerable time, requiring 

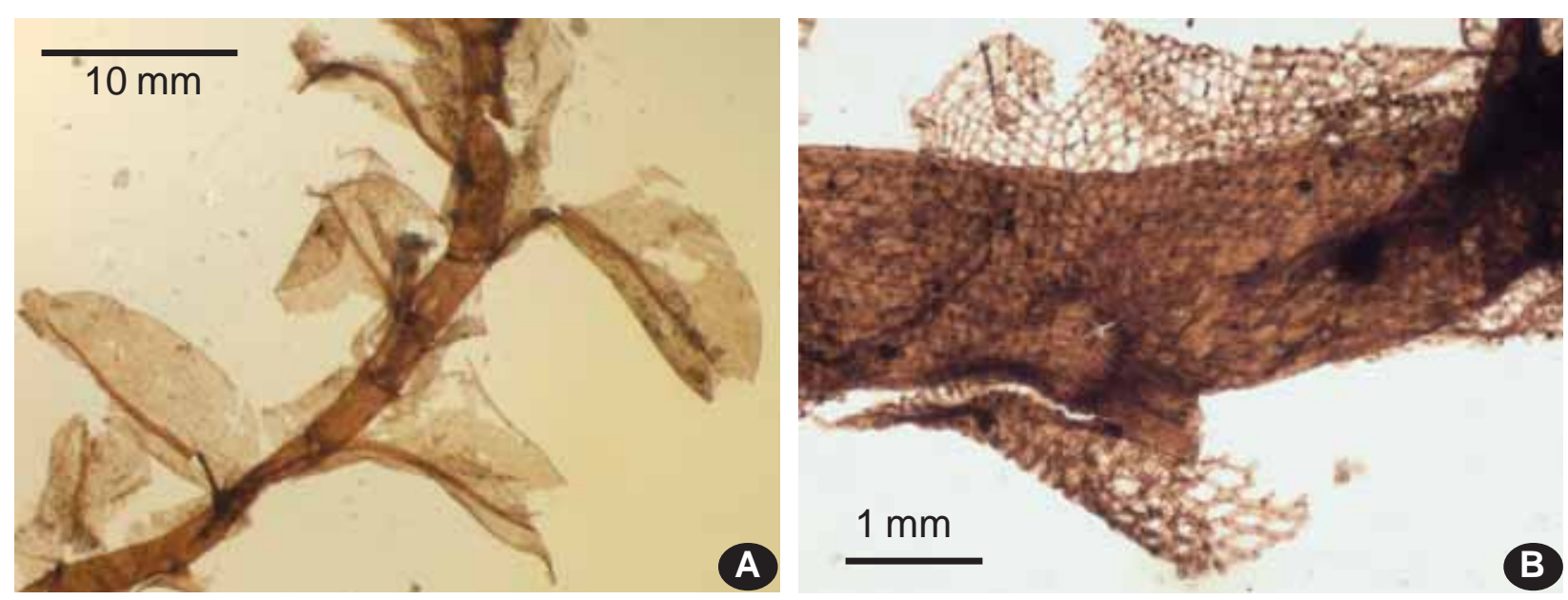

Fig. 2. Protosphagnum nervatum Neub. (GIN 3774/3B-7, Tatarian Stage of Upper Permian, from Viled, for locality description see Gomankov \& Meyen, 1987). A: habit; B: stem with auriculate leaf base, so leaf insertion is almost equal to width of costa.

understanding of variation in these plants and revision of the type collections of M.F. Neuburg and L.A. Fefilova. The present paper presents a small part of this study, focusing on an interesting morphological peculiarity.

We found out that zones of small cells within leaves are arranged in a way as it never happens in the modern mosses ${ }^{1}$. Since this difference is presumably important for understanding both leaf development and their overall variation, a special study on distribution of small cells was undertaken.

The selection of specimens for this study was rather straightforward. All leaves and leaf fragments which have small cells almost throughout or, more commonly, have conspicuously smaller cells in certain parts of leaf, were analyzed. By analogy with modern mosses, where the areas of active cell divisions look the same, we interpreted these zones in Palaeozoic moss leaves also as zones of cell division and/or early stages of their elongation. Altogether about 90 specimens of this kind were found in the studied material, which constitute ca. $10 \%$ of all moss specimens.

\section{METHODS}

To extract the moss and other plant remains from inorganic matter, the standard bulk-maceration method was used (Andrews, 1961; Darrah, 1960). The fragments of rock were placed into $50 \%$ fluoric acid during 14 days or more. The duration of the procedure was determined and controlled by experience. The products of bulk-maceration were washed by distilled water. The moss remains were extracted by infiltration through sieves and mounted in permanent glycerin-gelatin slides. The material is kept in the Main Botanical Garden of the Russian Academy of Sciences (Moscow), collection Adzva32.

\footnotetext{
1 - Although all genera from the studied collection belong to Protosphagnales, there are other Palaeozoic groups (see, e.g. Ignatov, 1990) similar to modern Bryopsida. They are known not enough to be evaluated for their leaf developmental patterns, but comparatively with Protosphagnales at least some of them could likely be classified as modern.
}

\section{GENERA AND SPECIES IDENTIFICATION}

The material obtained from bulk maceration is represented mostly by leaf fragments. This reduces the possibility for identification, and not every fragment can be referred to species and even genus. Moreover, the present material reveals at least few cases where diagnostic characters of different genera were combined in a single leaf (Figs. 39, 43).

It should be mentioned that juvenile leaves of modern mosses are also impossible to identify using any existing handbooks and taxonomic revisions. In vascular plants, there are special manuals for seedling identification, while in mosses the possibility for identification of young leaves, say $0.1 \mathrm{~mm}$ long, has never been even explored, because such leaves occur among well-developed ones, which have much better expressed diagnostic characters of species. So, in the present case, only approximate identity of many dispersed juvenile leaves is possible.

The identification, both preliminary or with confidence, was according to description of Neuburg (1960) for: Intia angustifolia Neub., I. variablilis Neub., Vorcutannularia sp., Protosphagnum nervatum Neub., Junjagia glottophylla Neub., and of Fefilova (1978) for Kosjunia sp., and by comparison with their original collections.

It is important to consider that identification in many cases is 'indirect', i.e. by similarity in areolation of 'nontypical' part of leaf, which in its other parts is 'typical'. For example, Fig. 46 shows Junjagia, where its typical dimorphous areolation is represented (Fig. 46, above); another part of the same leaf, shown in Fig. 45, totally lacks its main diagnostic characters. The leaf in Fig. 49

Fig. 3. Scheme of cell divisions leading to T-shaped pattern and TT-shaped pattern

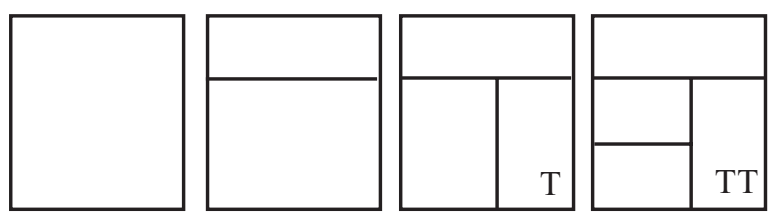


is similar in areolation and overall texture to that in Fig. 45 , and by this reason is referred to Junjagia, despite no diagnostic characters of the genus are available neither in the specimen in Fig. 49, nor in Fig. 45.

However, regardless the mentioned difficulties, the essential characters of Protosphagnales are apparent in the whole present collection, thus we are certain that their affinity to this order is doubtless.

\section{DiAGNOSTIC CHARACTERS OF PROTOSPHAGNALES}

Plants large. Leaf foliage remote (Fig. 2A), more rarely moderately dense, leaves arranged in a spiral close to $1 / 3$ (i.e. including $2 / 5$ and $3 / 8$ ). Leaves from erecto-patent to wide-spreading or somewhat reflexed, ovate to elongate, obtuse, tapered to leaf base or widely auriculate, but in all cases leaf insertion to stem is very narrow (Fig. 2B), including almost only costa, no decurrencies observed; costa extending up to 0.7-0.9 the leaf length, narrow, sometimes forking near end and occasionally with lateral offsprings; margin bordered throughout by 1-3 rows of elongate unistratose cells; border cells 2-4 times longer than adjacent inner cells, outer border cells with characteristically curved and protruding upper end, making margin crenulate throughout or in distal leaf or, rarely, poorly expressed; laminal cells monomorphous or dimorphous, often in conspicuous rows, in well-developed leaves T-shaped patterns of cell arrangement can be found at least in proximal part of leaf.

T-shaped pattern is formed when cell undergoes two divisions: the first is subequal to unequal and can be either transverse or longitudinal; the second division is perpendicular to the first one and happens in only one of two cells appeared from the first division, in the larger one if the first division was unequal. Thus, the cell walls of these two divisions look like "T" (Fig. 3), and the term "T-shaped pattern" will be used in further discussion, as it is very common in the Protophagnales and important for taxa differentiation. Sometimes this pattern develops further and forms tetrads by an additional division of one cell of a triad, perpendicular to the previous division. Such pattern will be called "TT-shaped pattern" (Fig. 3).

The general habit of Protosphagnum nervatum Neub. is shown in Fig. 2. In addition to cell dimorphism, the conspicuously regular cell rows, cell arrangement in triads or tetrads, always present border of uniform structure, and attachment to stem by narrow area, which involves almost only costa, allow referring all nine genera described by Neuburg and 2 additional genera described by Fefilova to one group, Protosphagnales.

As we will try to show below, the late cell differentiation in apical, median and basal parts of leaf can be an additional characteristic of the group, providing further contrast with the modern mosses.

\section{LEAVES UNDEVELOPED VERSUS UNDERDEVELOPED}

This antinomy is quite clear in general. Leaves developing in proximal parts of branches, on tiny shoots in unfavorable conditions and in other similar situations never have a chance to reach the size maximal for the species. At the same time such small leaves have a better chance to be found in a well preserved state in fossil collections obtained from bulk maceration, which favors small fragments. Comparatively with Neuburg's material, where numerous foliate shoots were seen on rock surface, bulk maceration of argillite never yields foliate shoots and very big leaves, similar to those obtained on rock surface for Vorcutannularia, which is probably the largest (in terms of its area) moss leaf ever known in the whole moss evolution, being $16 \times 8 \mathrm{~mm}$.

Young undeveloped leaves are difficult to obtain for two reasons. First, they usually occur within the leaves of apical "buds" which are rare in our collection (Figs. 73-74). Both folded and overlapped leaves in our bulk maceration material were extremely difficult to separate: they are so fragile, that the best method of their study is just the mounting them in slide and sectioning with microscopy. However, delicate thin-walled cells surrounded by several layers of much more developed leaves can not be studied this way. Even separated from the bud, such leaves are composed of so thin-walled cells that the probability of decomposition during fossilization and during maceration in acids together with numerous plant fragments considerably reduces a chance to catch such stages. The smallest of obtained leaves are shown in Figs. $38,51,71-72,75-78$.

Fortunately, lucky combinations of partly undeveloped and partly underdeveloped leaves were found in the bulk maceration material, thus allowing arrangement in series and comparing specimens among themselves, as well as with the modern mosses.

Leaf development in modern mosses was described in many publications (e.g., Lorentz, 1864; Müller, 1906), in most details published by Frey (1971). Leaving aside discussion of Andreaopsida, Andreaobryopsida, Sphagnopsida and Takakiopsida, the scheme of differentiation is as follow:

1) The apical cell in a series of divisions produces cells that further form sectors (cf. Fig. 80: A1-A2). These mother cells of sectors are rather few, e.g. in Physcomitrium 6 to 12, or three to six on each side of costa (cf. Donskov, 2012).

2) In most groups of modern mosses, cells in distal sectors are differentiating earlier than in proximal ones, so undifferentiated small cells remain near leaf base longer than in other parts of leaf.

2a) Exceptions of (2) exist in species with especially large leaves, like Plagiomnium, where small cells in distal half of leaf do not undergo enlarging immediately after their origin, pausing the process of elongation until the later stage, when large cells already appear in proximal part of leaf. Interestingly, not all Plagiomnium species have this order in leaf development: $P$. cuspidatum (Hedw.) T.J.Kop., for example, in this respect is more similar to Funaria, than to species of Plagiomnium af- 
fine (Bland.) T.J.Kop. group and P. undilatum (Hedw.) T.J.Kop. group. Note, however, that in two latter groups of species, small cells in subapical part are never arranged in rows towards the apical cell and never constitute whole leaf sectors across the leaf width.

The study of Protosphagnales leaves with undeveloped parts reveals considerable differences in areolation patterns in both apical, median and basal parts of leaves, probably reflecting principally different way of leaf morphogenesis in this early group of bryophytes.

OBSERVATIONS ON THE APICAL ZONE OF LEAVES

The most common situation in modern mosses is that the apical cell is usually apparent and it alternately produces to two sides 'mother-cells of sector'. The latest 24(-6) sectors are almost always traceable at least near leaf apex. In obtuse leaves, this pattern is not so apparent in fully developed leaves, although seen better in young leaves.

Contrary to this, in Protosphagnales:

1) The apical cell is never conspicuous (Figs. 14-24).

2) In some young leaves, in the apical zone, there are numerous small quadrate and rectangular cells, with cell angle joints forming crosses (Figs. 4-13), the latter being a mark of zones of active cell divisions; important is that such leaves have lamina where most cells look fully developed (e.g. of the same size as in similar leaves without any differentiating area).

3) Cells at the early stage of elongation appear in conspicuous rows, which can be traced in much lower sectors of leaf lamina (Figs. 13, 18, 30)

In leaves with still active divisions in apical part, sectors are difficult to trace definitely, although in older leaves, sector outlining is usually unequivocal or at least at the same level of clarity as in modern mosses (Figs. 14-24)

The shape of leaves in Figs. $6,8 \& 11$ suggests that they may continue growth in apical part after a considerable (or even most) part of leaf is already formed by cells which have reached their normal size. The argument for this is that in most part of leaf except its apical part, cell size is the same as in other leaves that look more or less fully developed.

If this is correct, the analogy in modern mosses would be difficult to find. In the Mniaceae (e.g. Plagiomnium undulatum, our unpublished data) early divisions produce numerous small cells which are awaiting the right time for their elongation, forming opaque subapical area. However, their arrangement never shows any continuing activity of the leaf apical cell.

In Protosphagnum an undifferentiated subapical zone in some leaves has a rather distinct appearance: smaller cells occupy a considerable area, but do not exhibit apparent cell rows towards the apical cell (Fig. 25). At the same time, in some other specimens of Protosphagnum undifferentiated cells occur in the juxtacostal zone in the median part of leaf, whereas in Intia angus- tifolia the apical part is the only place where small cells are seen.

It is worthy noting that the apical part in Intia angustifolia and some specimens of Intia sp. is usually reflexing, which is an additional evidence for cell division activity there. It is easy to imagine how the tension from newly appearing and even slightly elongating cells shifts the whole mass of dividing cells out of the leaf plane (Figs. 4, 5, 8, 20, 30).

OBSERVATIONS ON THE MEDIAN ZONE OF LEAVES

Probably the most unusual for mosses is the zone of small undeveloped cells in the median part of leaf found in some specimens of Protosphagnales (e.g. Fig. 33).

This zone is usually seen across the whole leaf and closer to the apex. Sometimes it marks the line of reflexion (Figs. 28-30).

The median part of leaf may consist totally of small quadrate and homogeneous cells, or include partial differentiation, like in Junjagia (Fig. 45), where the Tshaped pattern has already appeared, but further development to dimorphous cells (Fig. 46) occurs only along the upper border of zone of small cells.

Sometimes undeveloped cells are already differentiated in a pattern characteristic for the fully developed part of leaves, for example in Vorcutannularia (Fig. 39). The undevelopment in this case refers just to their smaller size.

Distal and proximal edges of this zone of undeveloped cells exhibit trends to elongation only (Figs. 32, $33,35,36$ ) or both elongation and differentiation (Figs. $34,43,46)$.

Figs. $32 \& 35$ illustrate cell elongation at the lower edge of the zone of small cells, so their length increases 4-6 times compared with smallest undeveloped cells. At the same time, width increases very slightly and the number of rows remains constant. There are also examples where undeveloped cells are twice as narrow as more developed cells below, as their number in the half-leaf is twice as large (Fig. 35).

Cell dimorphism develops more often above a zone of small cells (Fig. 39, 43, 46), and only once it was observed below it (Fig. 34). Although the studied material is hardly sufficient for statistical estimations, it seems that the areolation below the zone of small undeveloped cells is usually more homogeneous than above it (cf. also Figs. 39-40, 42-44).

The cell dimorphism will be discussed in a separate paper in detail; the present observation, however, allows formulating the rule of their formation, the "fifth angle rule" (Fig. 47). As it is seen at the edges of zones of small cell, a slight shift of subtransverse oblique cell rows results in inequality of cells appeared in the latest division due to formation of a cell wall with one additional cell (arrowed). Thus, the cell to the left of " $T$ " remains quadrangular $(\mathrm{Q}$ in Fig. 47), while one to the right from " $T$ " becomes 'pentagonal' ( $\mathrm{P}$ in scheme), although two closely situated apices 

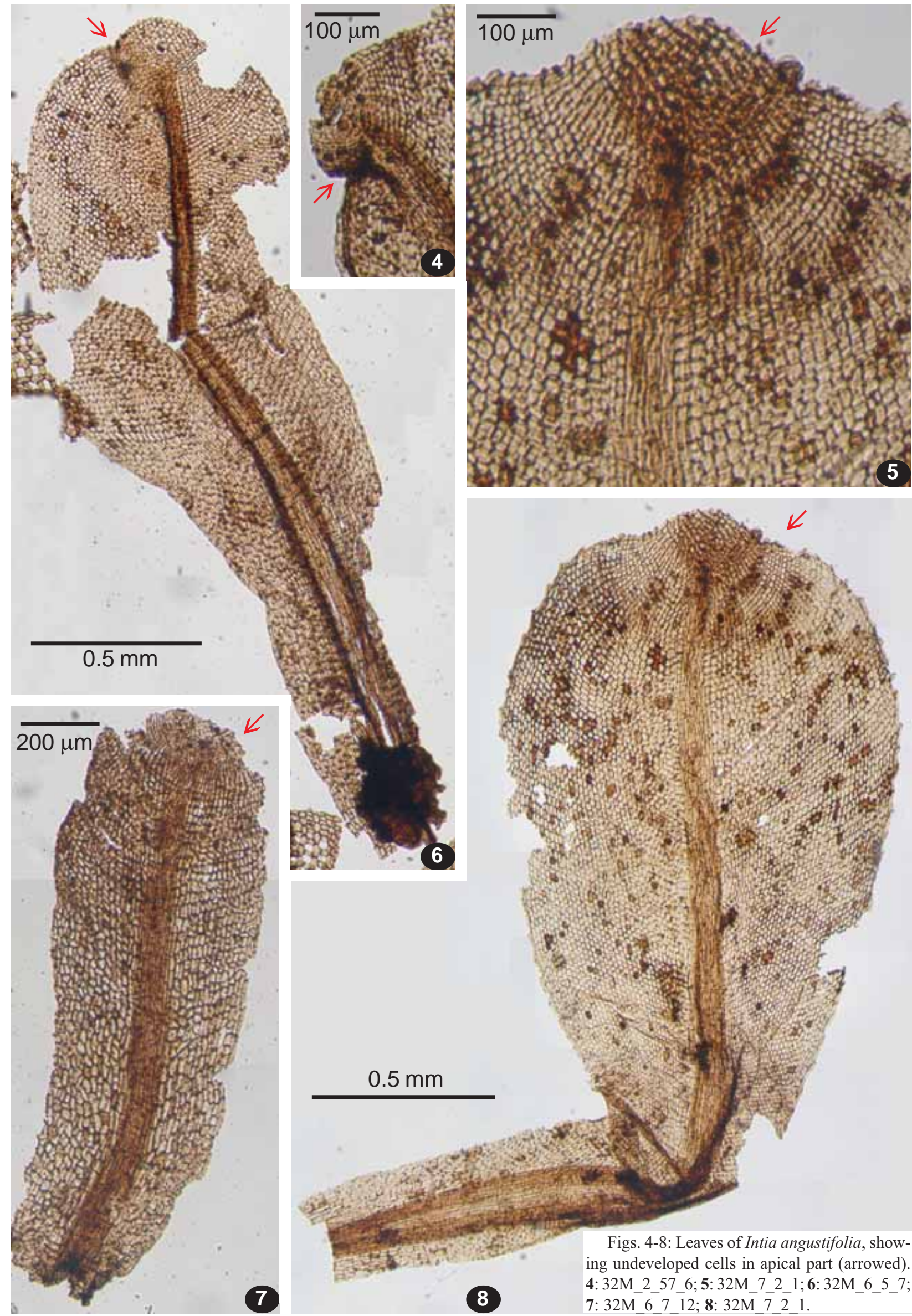

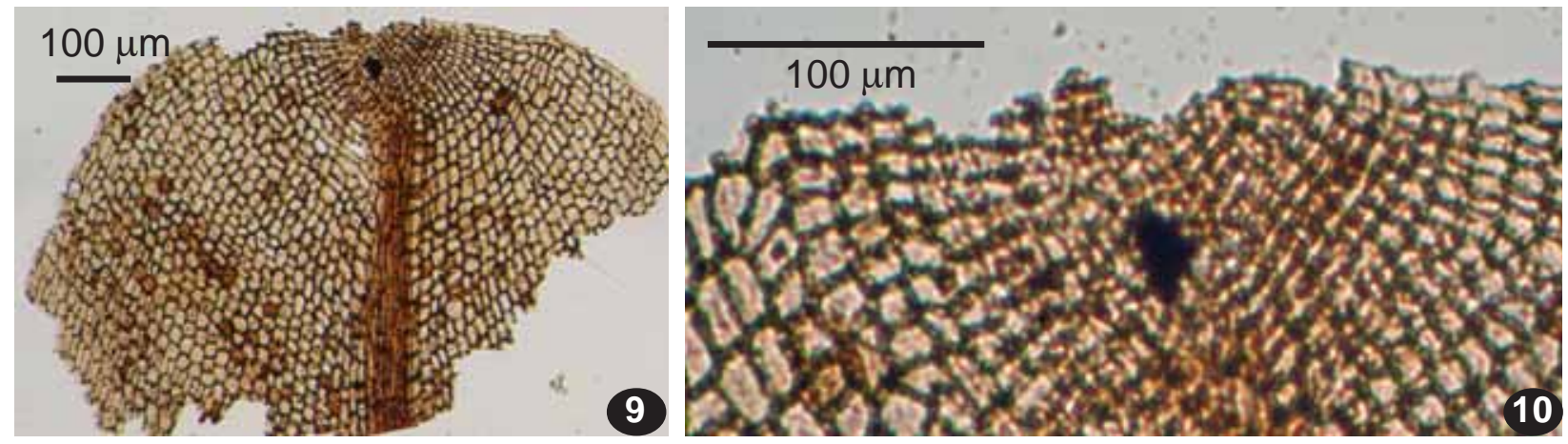

Figs. 9-13: Leaves of Intia angustifolia $(9-10,12)$ and Intia sp. $(11,13)$, showing undeveloped cells in apical part. 9: 32M_4_43_1, 10: 32M 4 43 1, 11: 32M 1 47 1, 12: $32 \bar{M}-5$ 14 3, 13: 32 $\overline{\mathrm{M}}-\overline{1} 4 \overline{7} 1$.
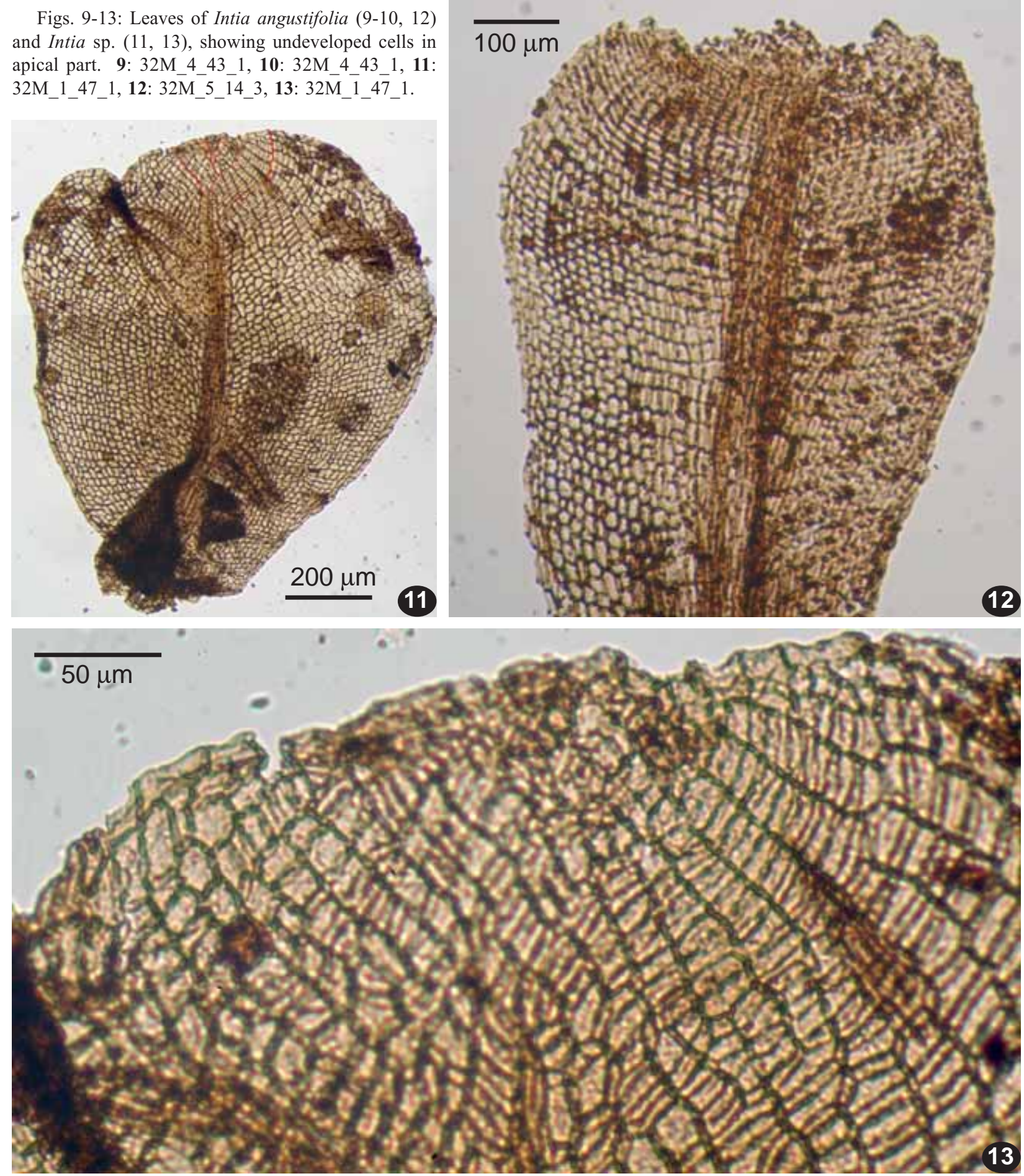

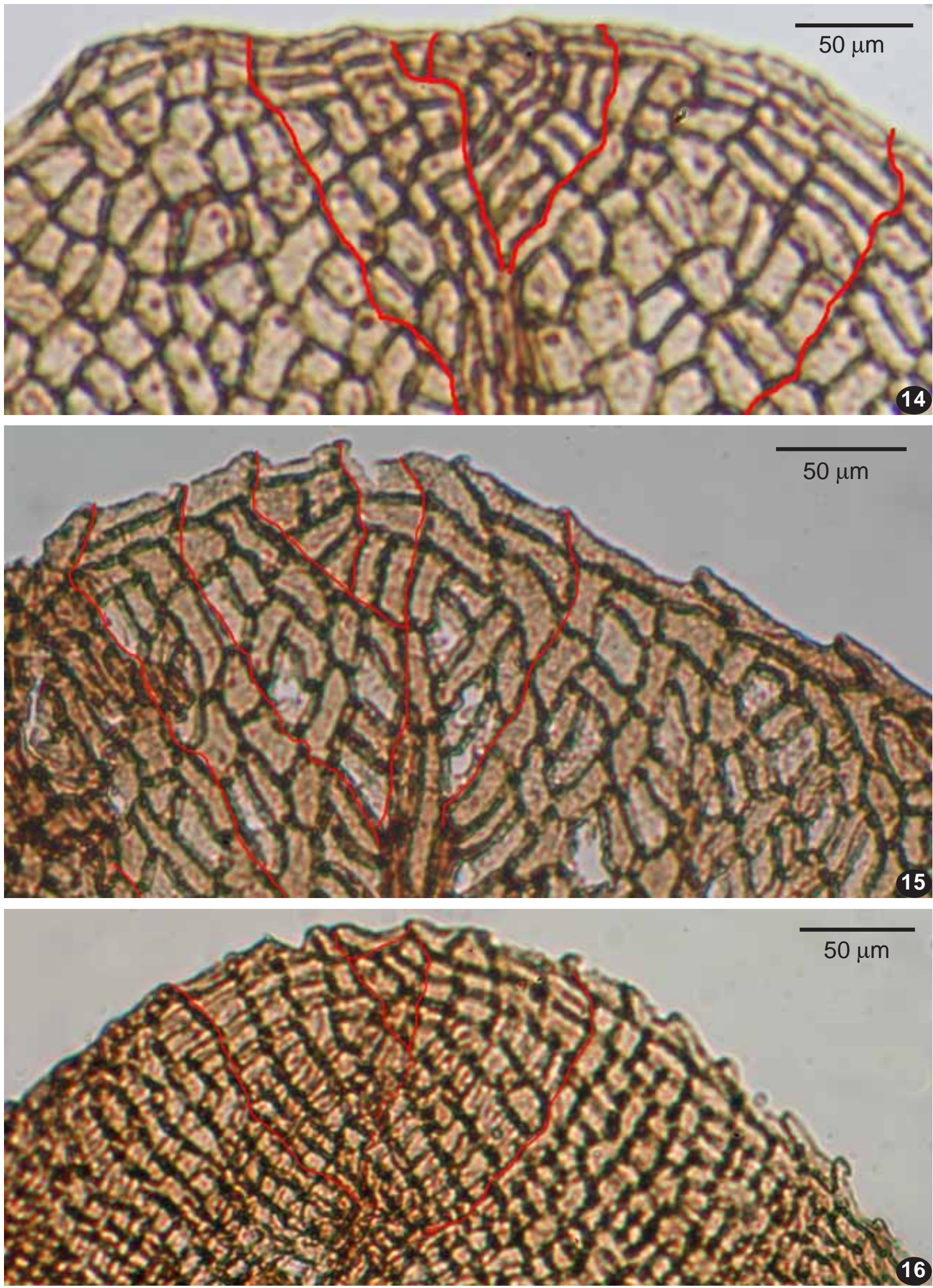

Figs. 14-16: Apical parts of leaves of Kosjunia sp. (\#14), Vorcutannularia sp. (\#15) and Intia variabilis (?)(\#16). Red lines indicate developmental sectors, what can be retrospectively traced, assuming classical scheme of leaf morphogenesis (cf. Frey, 1971). 14: 32M_5_22_3; 15: 32M_5_4_3; 16: 32M_2_27_2. 

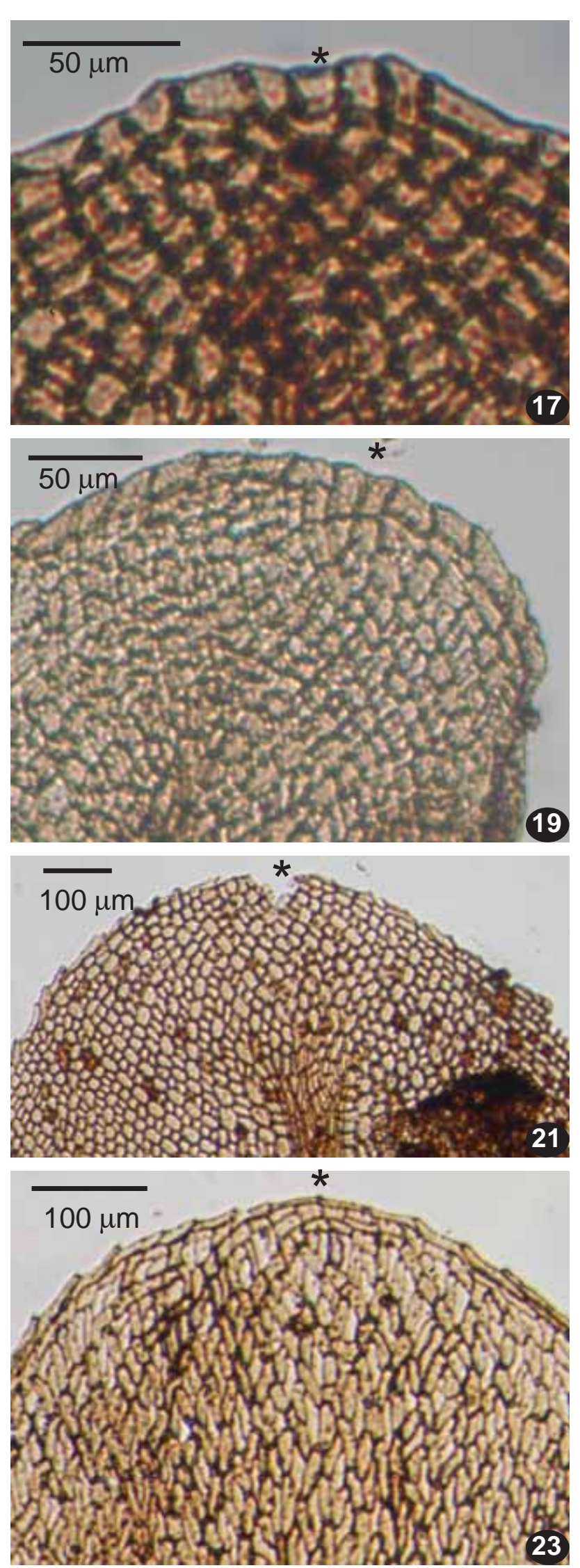
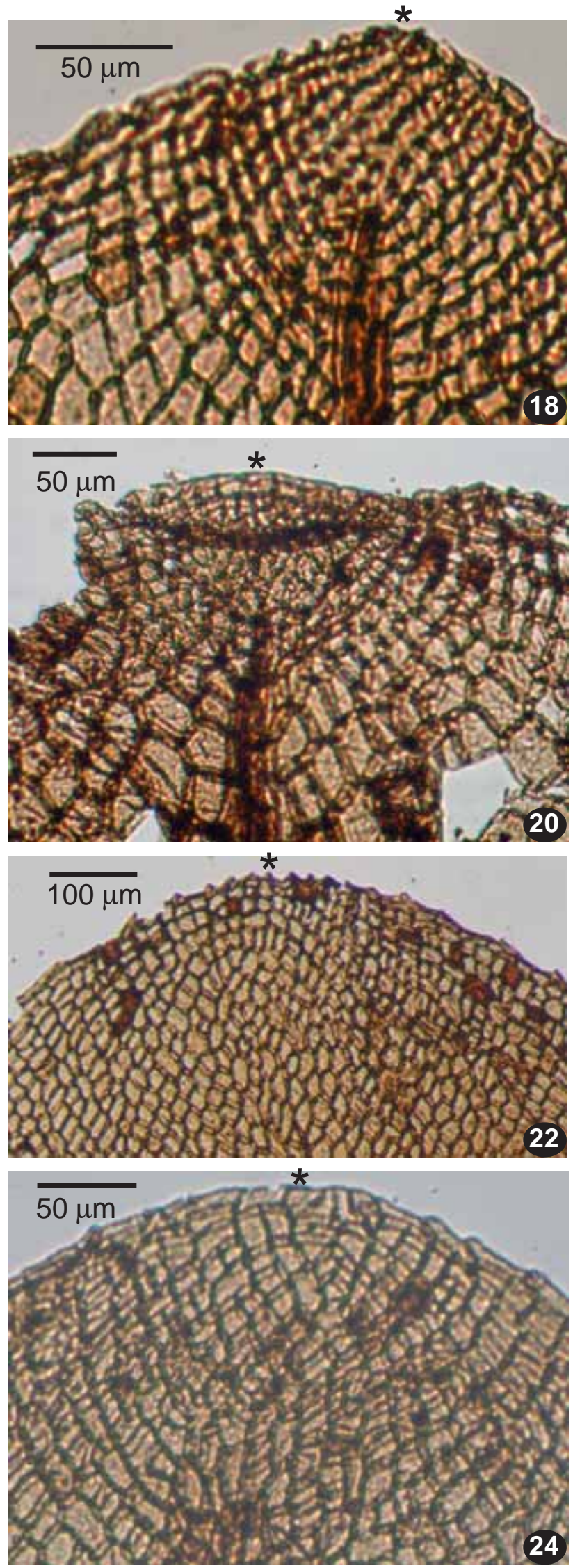

Figs. 17-24: Apical parts of leaves of Protophagnalean mosses: Intia sp. (?) (\#17-18, 20, 22, 24) Protosphagnum nervatum (\#19, 23) Protosphagnum nervatum (\#19) Kosjunia sp. (\#21), and Intia variabilis (?)(\#22). 17: 32M_4_83_1, 18: 32M_5_43_3, 19: 32M_1_51_1, 20:32M_4_82_1, 21:32M_7_1_1, 22:32M_7_3_7, 23: 32M_7_3_1, 24: 32M_1_16_1. Presumable apical cell is marked with asterisk $(*)$. 


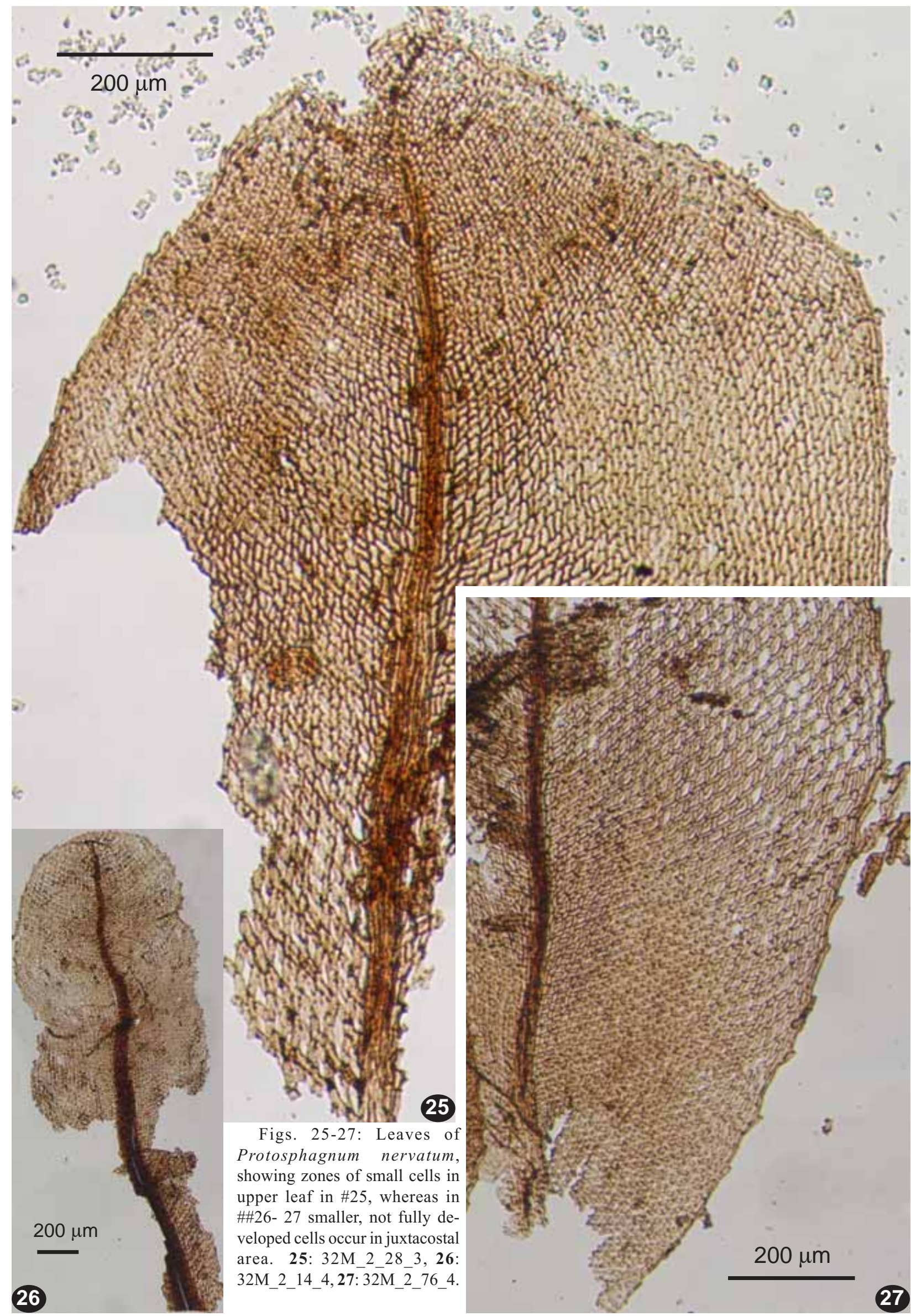



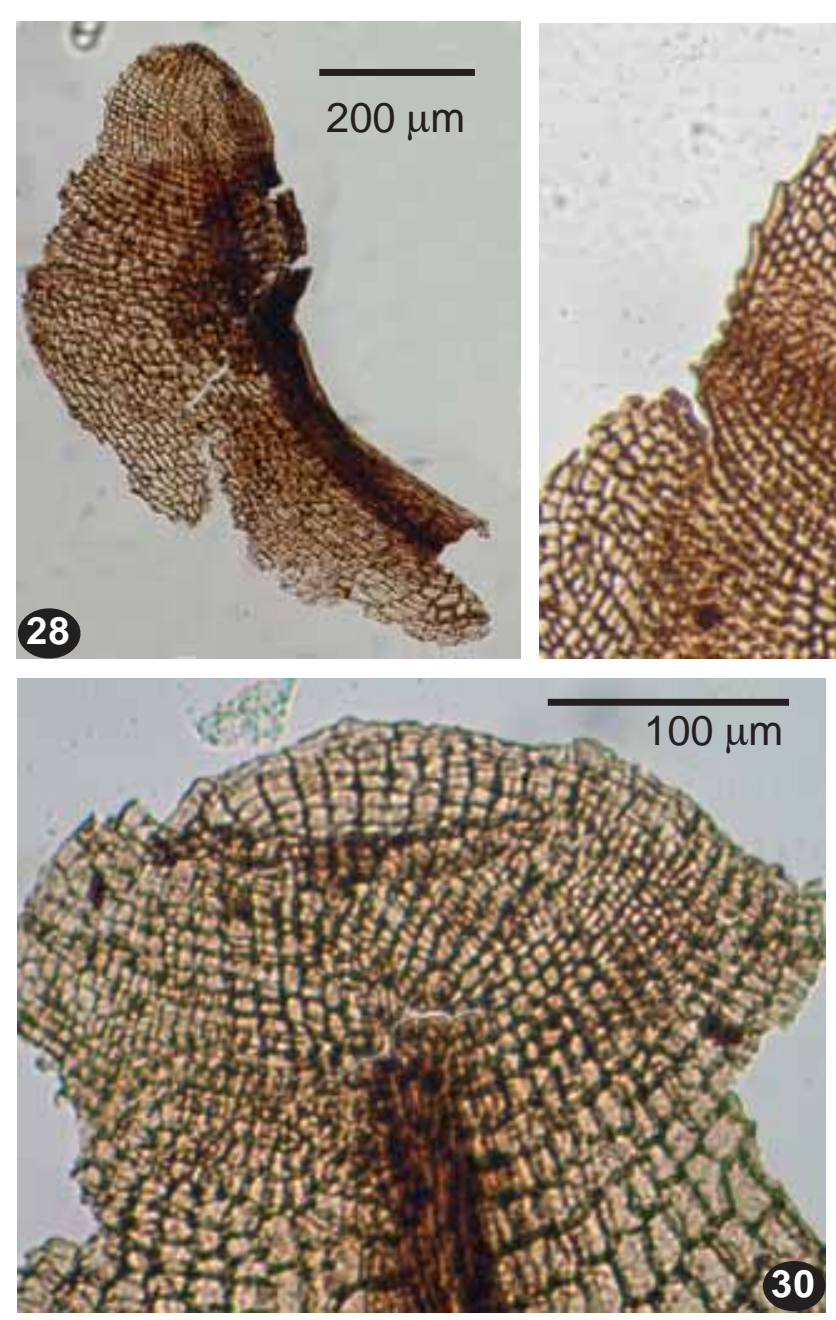

belong to the almost straight side of a cell, retaining its overall shape as quadrangular. In the course of further development such nearly quadrangular, but principally 'pentagonal' cells transform to darker cells along with the cells of transversal rows, thus forming "the net" ("chlorosyst analogs' in Neuburg terminology). At the same time, quadrangular cells transform to paler cells filling loops ('hyalocyst analogs' in Neuburg terminology). Cf. Fig. 3.

Sometimes (in Intia variablilis) small cells do not reach the costa, and the juxtacostal area is formed by larger irregularly polygonal-elongate cells (Fig. 37). This provides a contrast to Protosphagnum where juxtacostal cells are delayed in development comparatively with nearmarginal area, where cells are larger (Fig. 27). Note that the modern mosses have usually the former type, where cell size decreases from costa to margin (Ivanov \& Ignatov, 2013).

It is also important that zones of undeveloped cells in the leaf median part occur not only in young smaller leaves, but sometimes in quite large ones. For example, the leaf in Fig. 37 is ca. $3.7 \mathrm{~mm}$ long and apparently close to the size limit. This indicates that its development was quite gradual, allowing delayed development through elongation until the final stage of the leaf lamina formation.
Figs. 28-30: Upper part of leaves, showing zones of small cells across subapical part of leaves of \#28-29 Junjagia glottophylla; \#30 Intia sp. (?). 28: 32M_4_59_1; 29: 32M_4_84_1; 30: 32M_1_38_1.

OBSERVATIONS ON THE BASAL ZONE OF LEAVES

We can start this section with the parallel to the previous paragraph. Undifferentiated cells near leaf base are conspicuous in many leaves obtained from bulk maceration (Figs. 48-68), and this fact is strange itself. In modern mosses, in order to get such view one must separate an apical "bud", cut off leaves around it, and if succeeded to do this carefully enough, will be able to see undifferentiated cells at best in few leaves. In our material of Protosphagnalean mosses this pattern is observed not only in many, but also in not especially young leaves (Figs. 53, 64), e.g. in a leaf of Vorcutannularia which is $3.4 \mathrm{~mm}$ long (Fig. 68).

In young leaves, a zone of small cells is evenly constituting almost the whole leaf (Fig. 48, 76-77), and the later stages can be seen in leaves similar to those in Figs. 51 and 79, where small cells occur in the basal leaf, while cells in a more distal part of leaf are larger and all of about the same size.

In most cases (Figs. 53, 57, 59, 66-67), basal cells are of 4-5 $\mu \mathrm{m}$ and of square shape, i.e. the same as those found in proximal zones of active cell divisions in young leaves of modern mosses. Interestingly, in Vorcutannularia basal cells develop cell dimorphism already reaching size of ca. $10 \mu \mathrm{m}$ (Fig. 65), i.e. enlarging twice in linear size against the smallest size. The further enlarging of cells seems to proceed also gradually reaching maximal size of 30-60 $\mu \mathrm{m}$ in distal part of leaf (Figs. 61-66).

The conclusion can be that in basal leaf area differentiation proceeds rather gradually, not so rapidly as usually takes place in modern mosses.

As it was discussed by Ignatov (1990), the leaves of Protosphagnales are very unusual in their attachment to the stem by the costa only, having no decurrences. Of course, it is impossible to avoid some uncertainty on where the costa edge is. However, the rounding to the leaf base leaves a very narrow zone of attachment. 

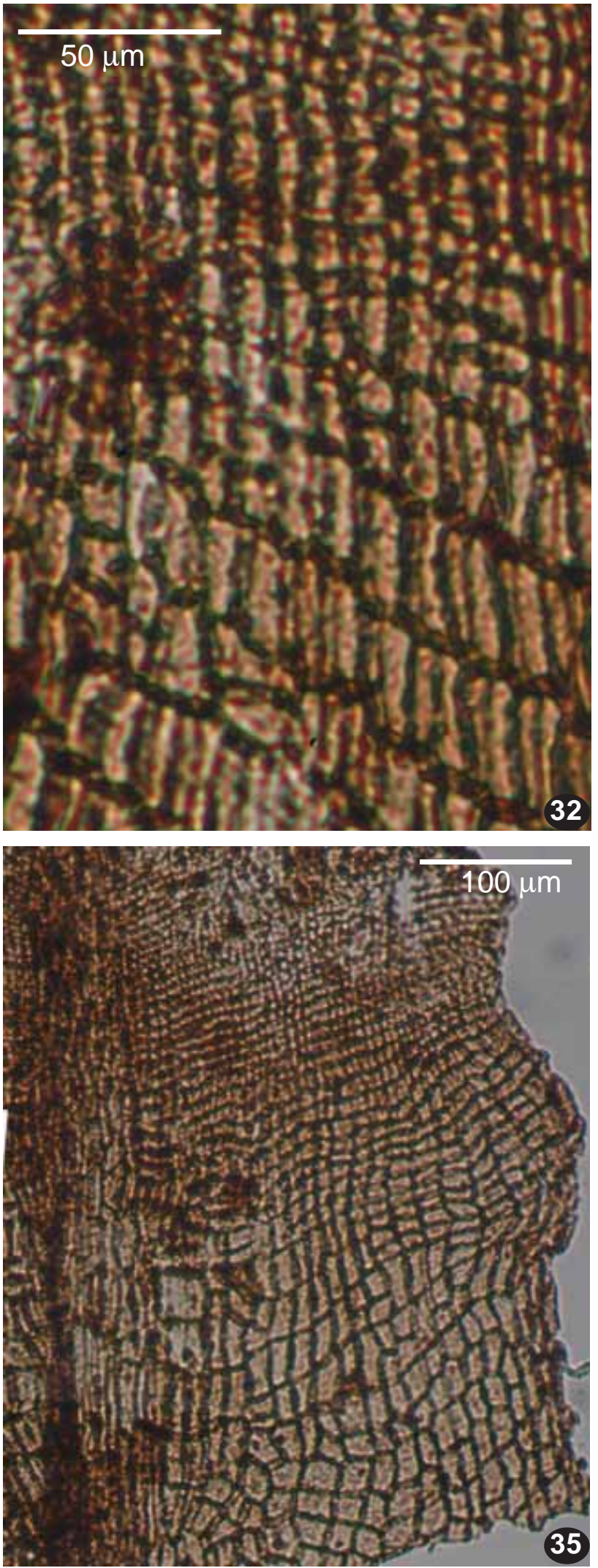

Figs. 31-36: Median part of leaves, showing zones of small cells: \#31-33 \& 35 Intia sp. (?); \#34 Junjagia glottophylla; \#36 Kosjunia sp. (?). 31: 32M_5_21_2; 32: 32M_5_21_2; 33: $32 \mathrm{M} 5212$; 34: $32 \mathrm{M} 6{ }_{4} 4 ; 35: 32 \mathrm{M} 6 \quad 20 \quad 6 ; 36$ : 32M_5_2_12.
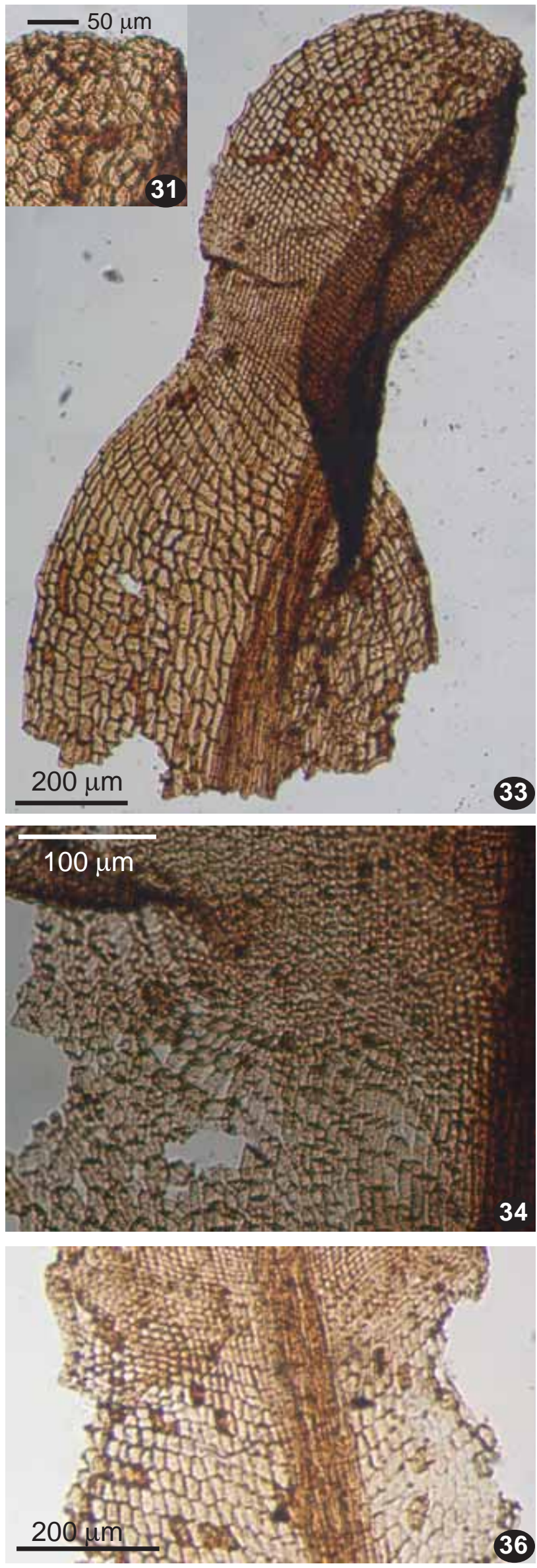


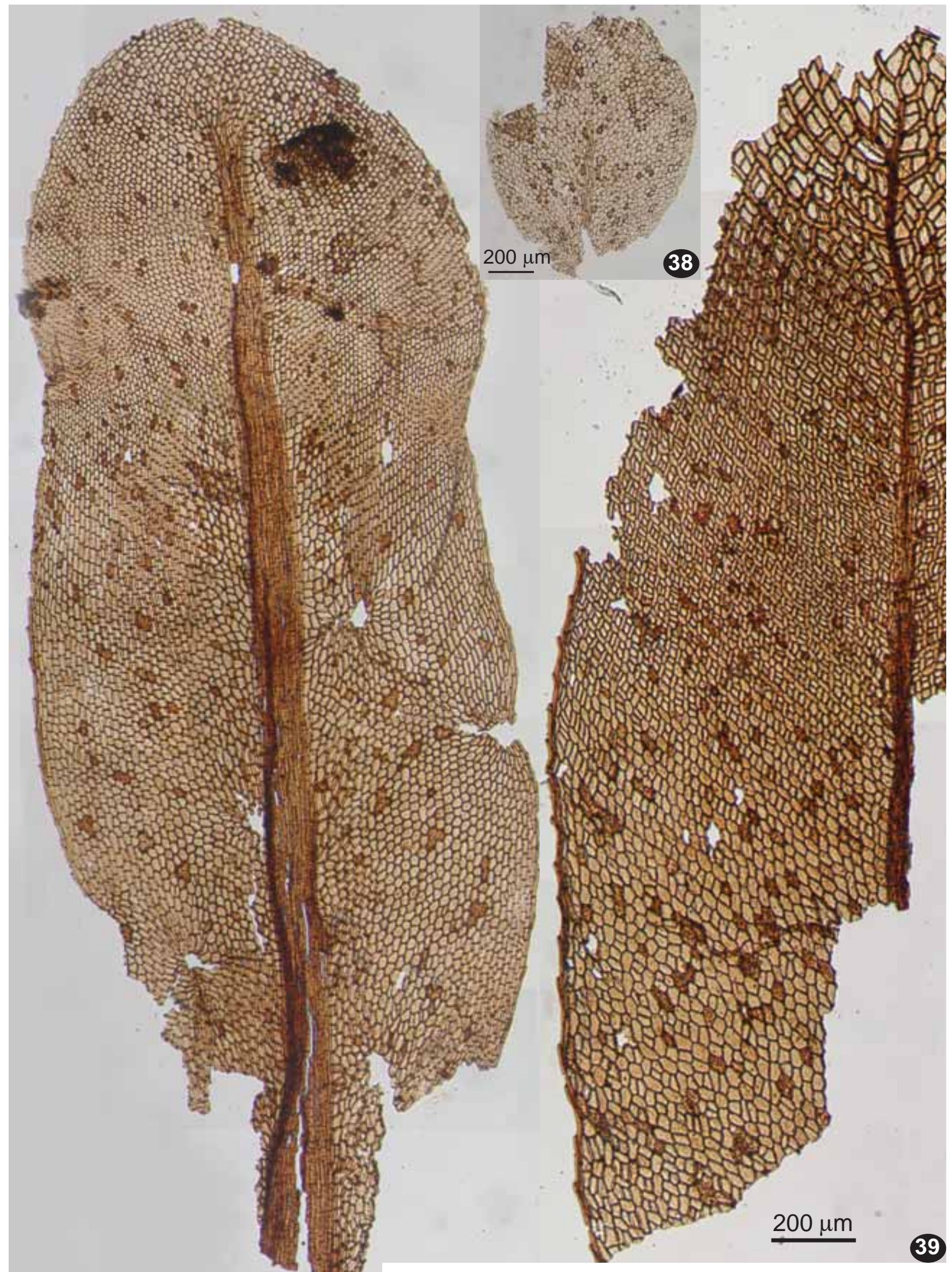

$200 \mu \mathrm{m}$

Figs. 37-39: Leaves of \#37-38 Kosjunia sp. and \#39 Vorcutannularia sp. (?). Note strong rounding to leaf base in \#38 and that in \#39 cell dimorphism is expressed above zone of smaller cells, while below cells are fairly monomorphous. 37: 32M_7_1_1; 38: 32M_4_56_1; 39: 32M_4_35_1. 

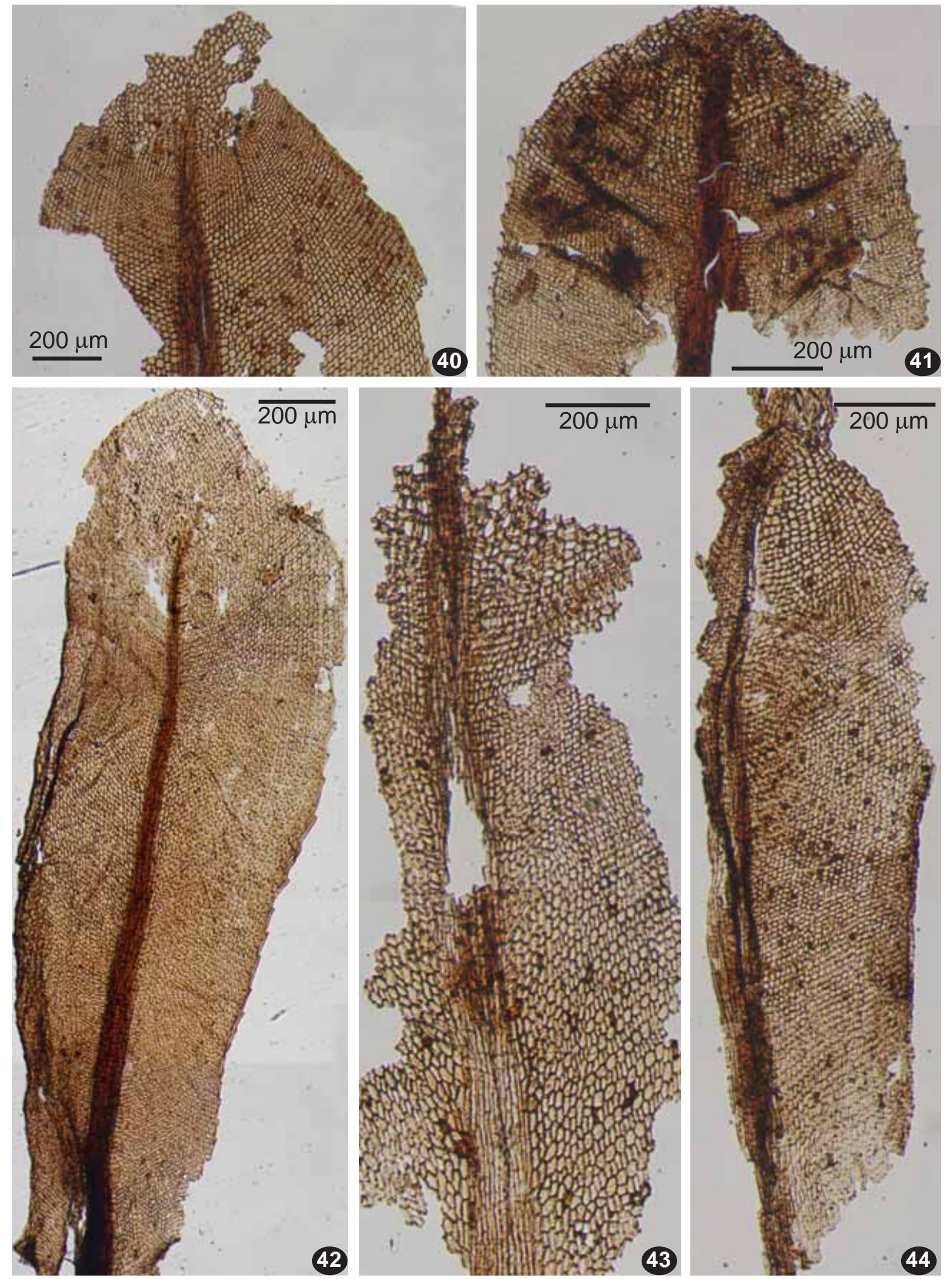

Figs. 40-44. Leaf fragments of Protospagnalean mosses, showing median zones of small cells: \#40 \& 42 Intia (?); \# 41 Junjagia glottophylla; \#43-44 Kosjunia sp. (?). 40: 32M_6_43_4; 41: 32M_4_22_1; 42: 32M_6_38_5; 43: 32M_2_59_2; 44: 32M_2_47_3. 

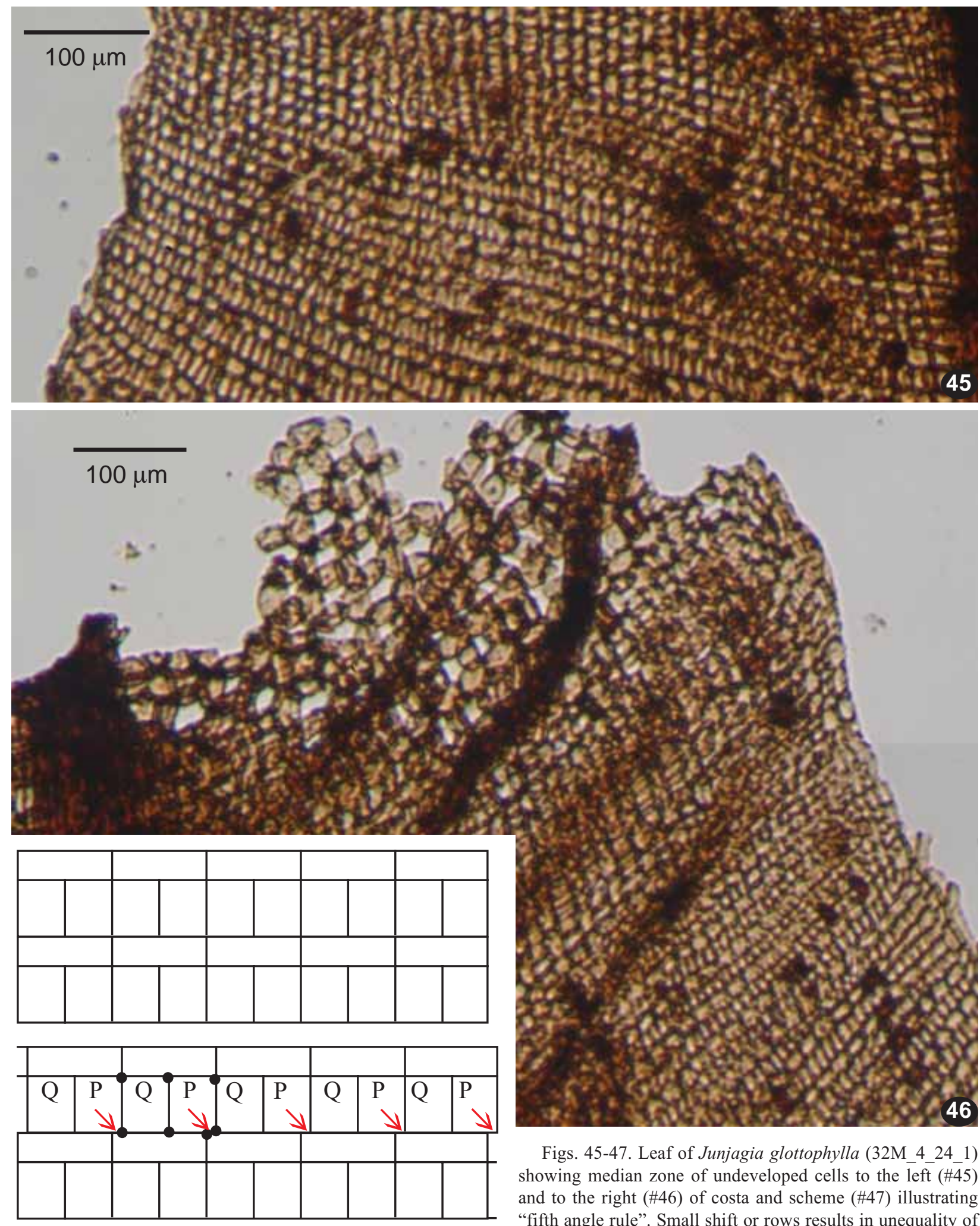

Figs. 45-47. Leaf of Junjagia glottophylla (32M_4_24_1) showing median zone of undeveloped cells to the left (\#45) and to the right (\#46) of costa and scheme (\#47) illustrating "fifth angle rule". Small shift or rows results in unequality of

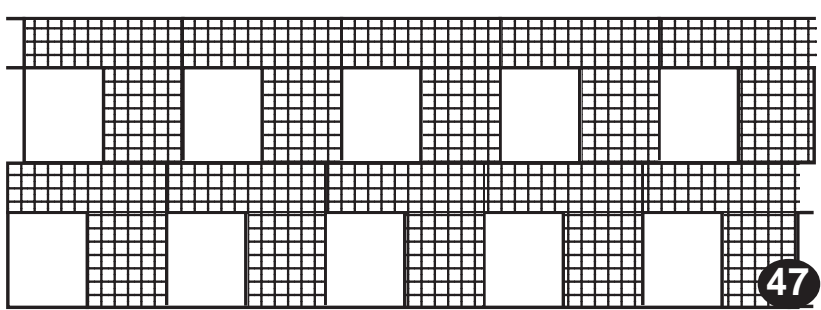
cells appeared in the latest division due to formation of cell wall with one additional cell (arrowed). Thus, one left of "T" remain quadrangular ( $\mathrm{Q}$ in scheme), while right of " $\mathrm{T}$ " became 'pentagonal' ( $P$ in scheme). In the course of further development pentagonal cells transform to darker cells forming "net" with cells of transverse rows ('chlorosyst analogs' in Neuburg terminology), while quadrangular cells transform to paler cells filling loops ('hyalocyst analogs'). Cf. Fig. 3. 

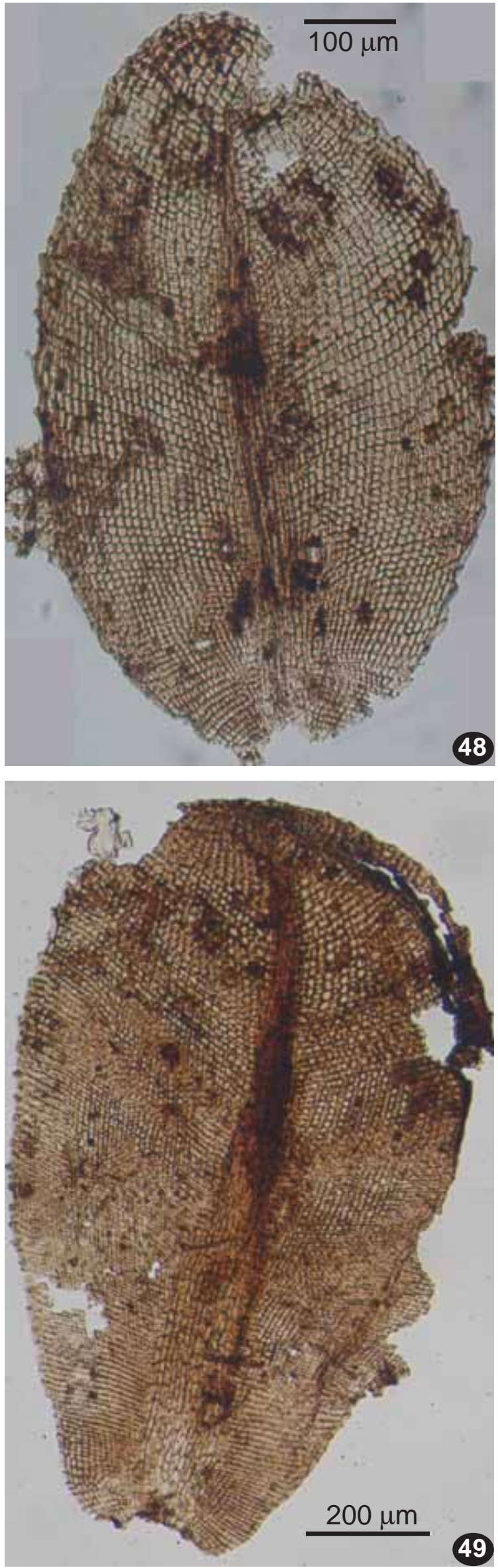

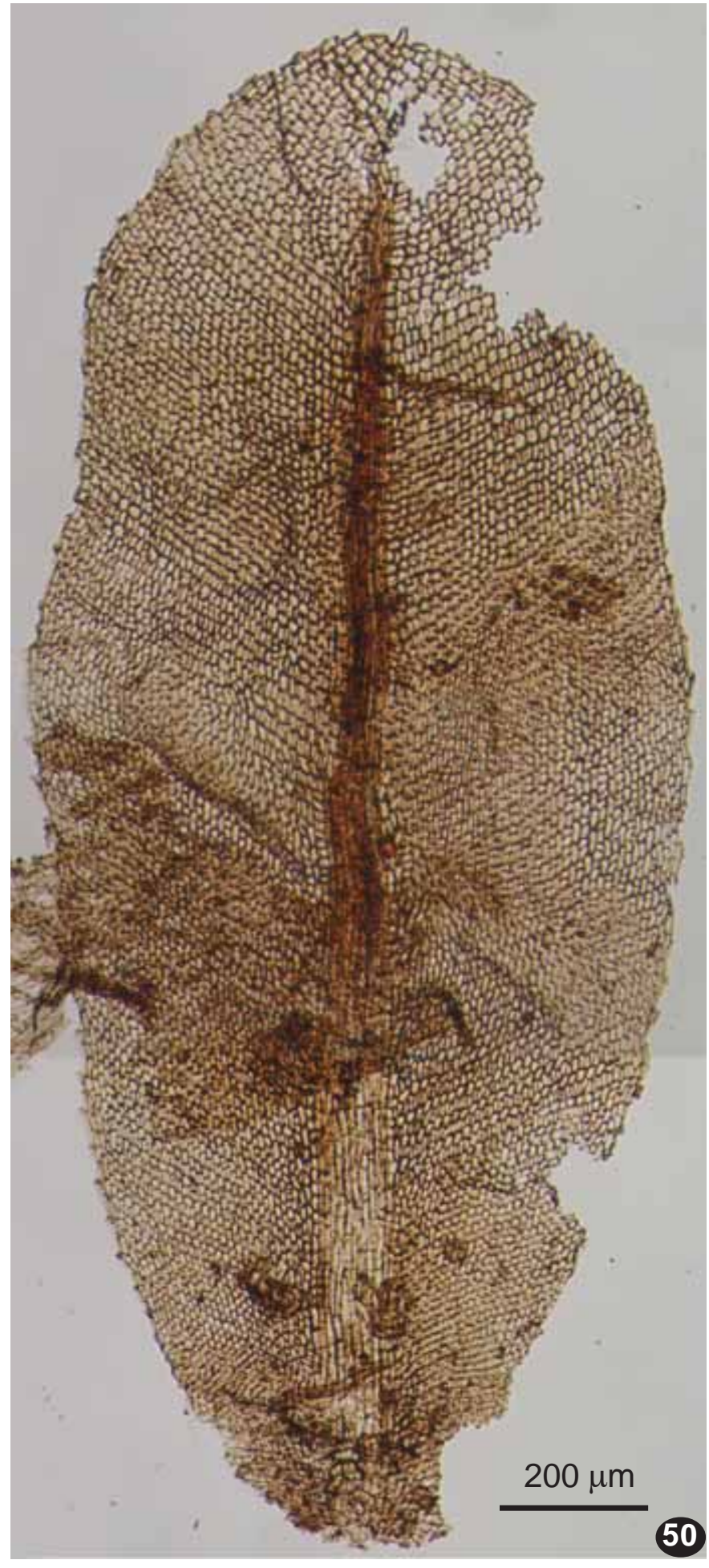

Figs. 48-50: Leaves of Protosphagnalean mosses, showing undifferentiated cells in their basal parts or almost throughout (\#48); \#48 younf leaf, likely of Kosjunia sp.; \#49 Junjagia glottophylla; \#50 Kosjunia sp. (?). 48: 32M 1105 1; 49: 32M 418 2; 50: $32 \mathrm{M} 2$ 16 1). Base of \#49 is magnified on $\# 57$. 

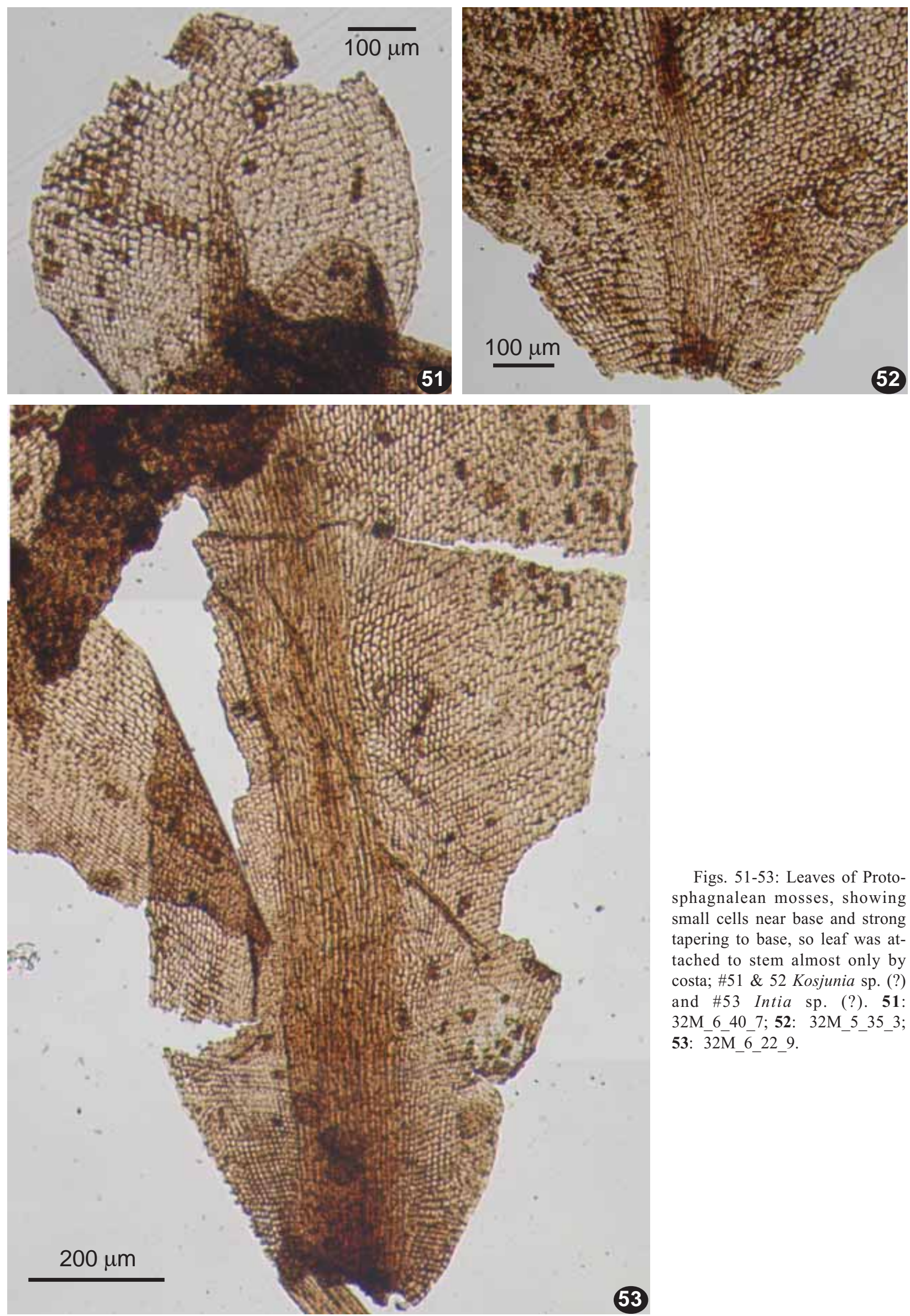

Figs. 51-53: Leaves of Protosphagnalean mosses, showing small cells near base and strong tapering to base, so leaf was attached to stem almost only by costa; \#51 \& 52 Kosjunia sp. (?) and \#53 Intia sp. (?). 51: 32M $6 \quad 40 \quad 7$; 52: $32 \mathrm{M} 5353$; 53: $\overline{3} 2 \overline{\mathrm{M}} \quad \overline{6} \quad 22$. 9 . 

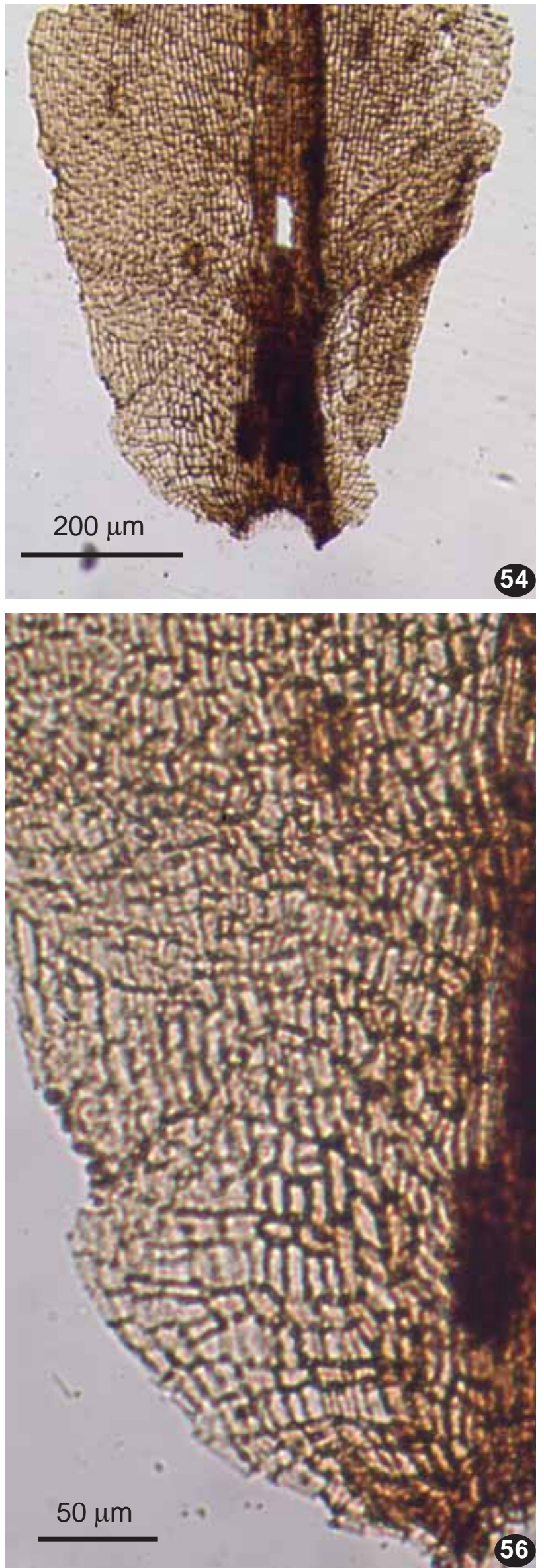
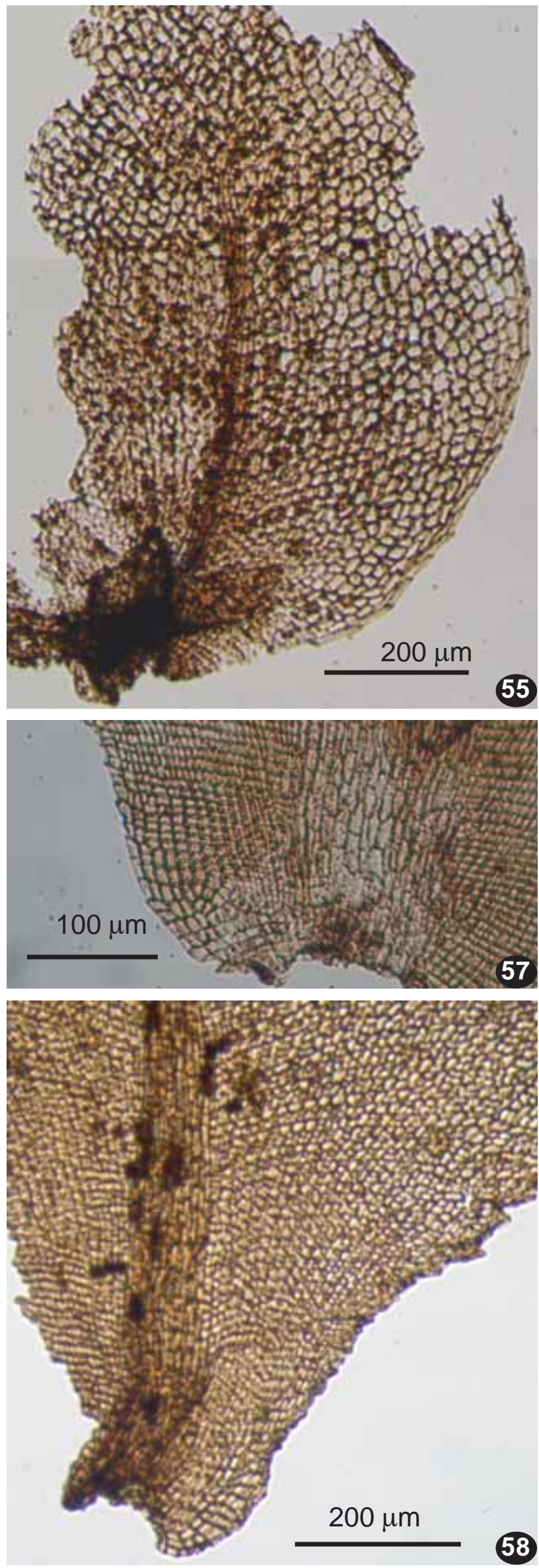


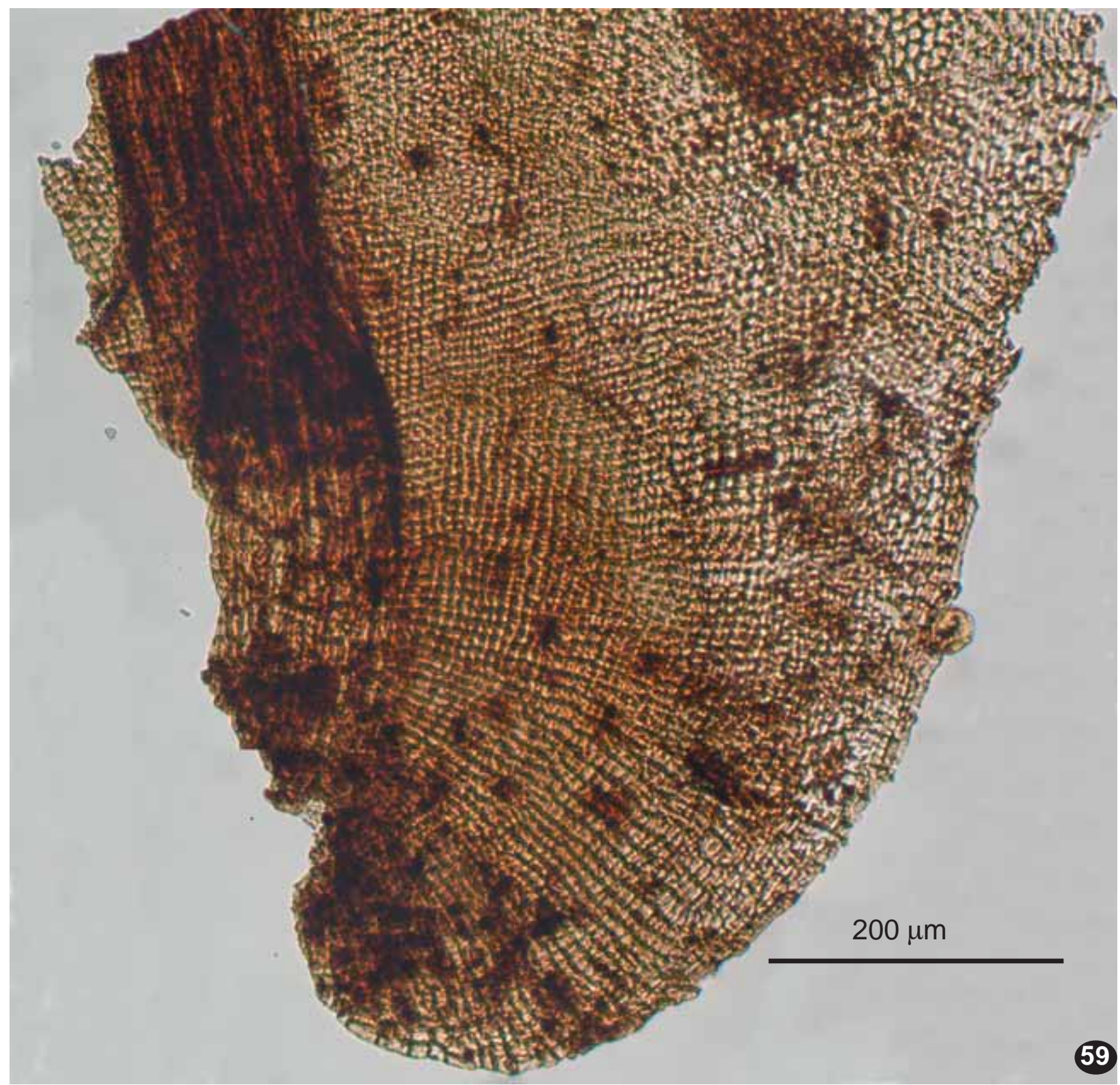

Figs. 59-60: Leaf bases of Junjagia glottophylla (\#59) and Intia sp. (\#60) showing early, \#60, and middle, \#59, stages of development of leaf auricules. 59:32M_2_39_1; 60: 32M_1_15_1.

Figs. 54-58 (opposite page): Leaf bases of Protosphagnalean mosses, \#54 \& 56-57 Intia sp. (?) and \#55 \& 58 Kosjunia sp. (?). 54: 32M_1_27_2; 55: 32M_1_27_2; 56: 32M_2_49_3; 57: 32M_ $\overline{4} \_18 \_2 ; \mathbf{5 8}$ : 32M_1_10_1. Larger fragment of \#57 is shown on \#49. Note strong tapering to base, so leaves were attached to stem almost only by costa.

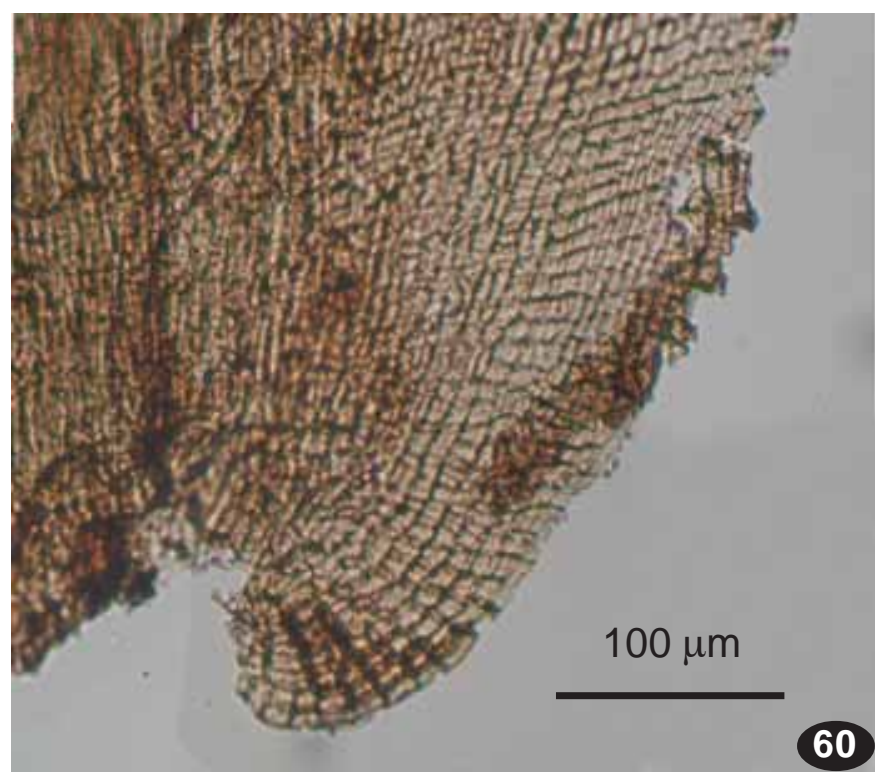



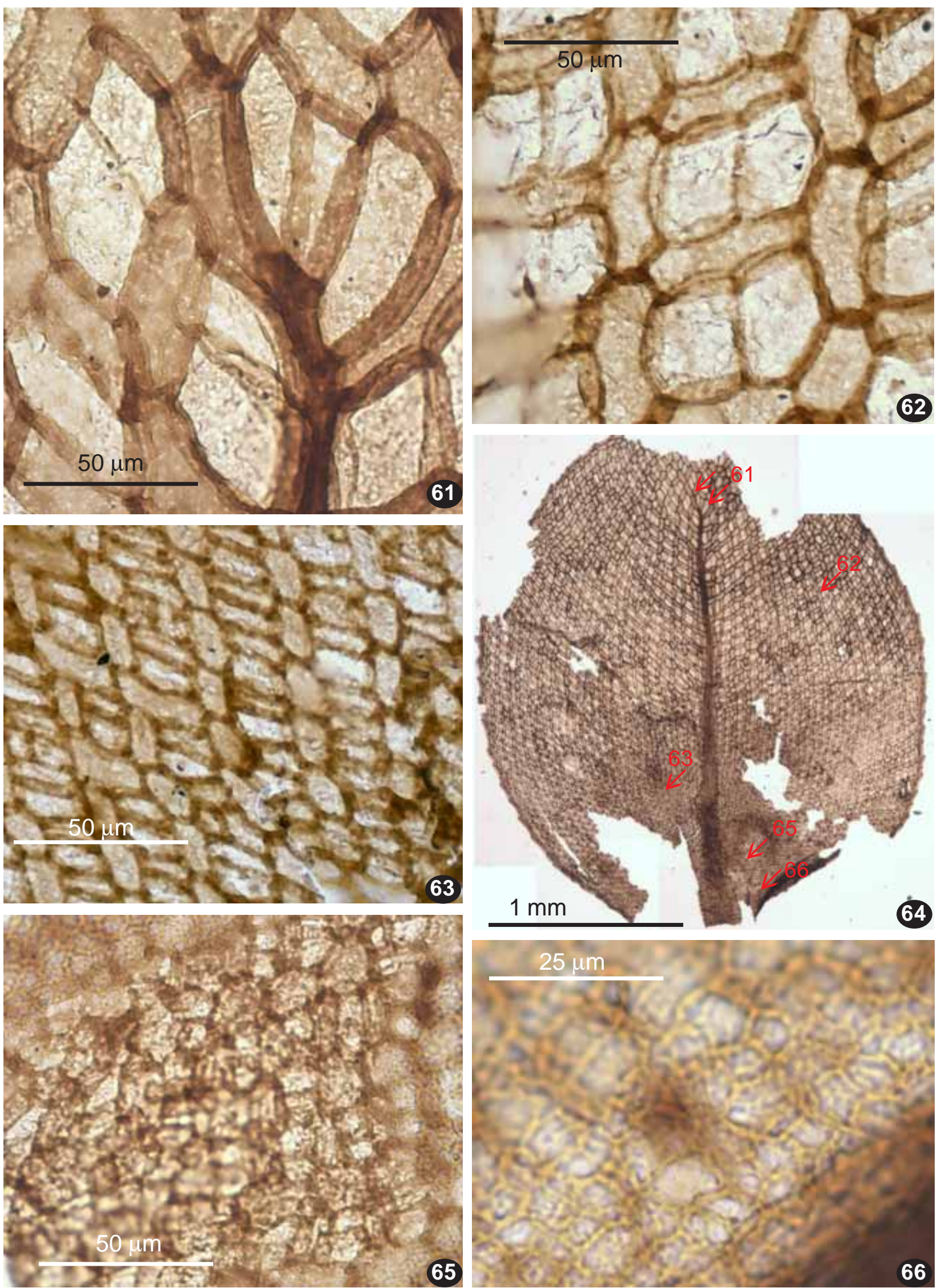

Figs. 67-72: Moderately young leaf of Vorcutannularia sp. (32M 55 1); places where cells were photographed shown in \#64. Note very small and thin-walled cells in the basalmost part, \#66. Magnification of 61-63 \& 65 is the same, thus showing string cell enlarging from bae to upper leaf. Most proximal cells (\#66) are on monomorphous stage. 


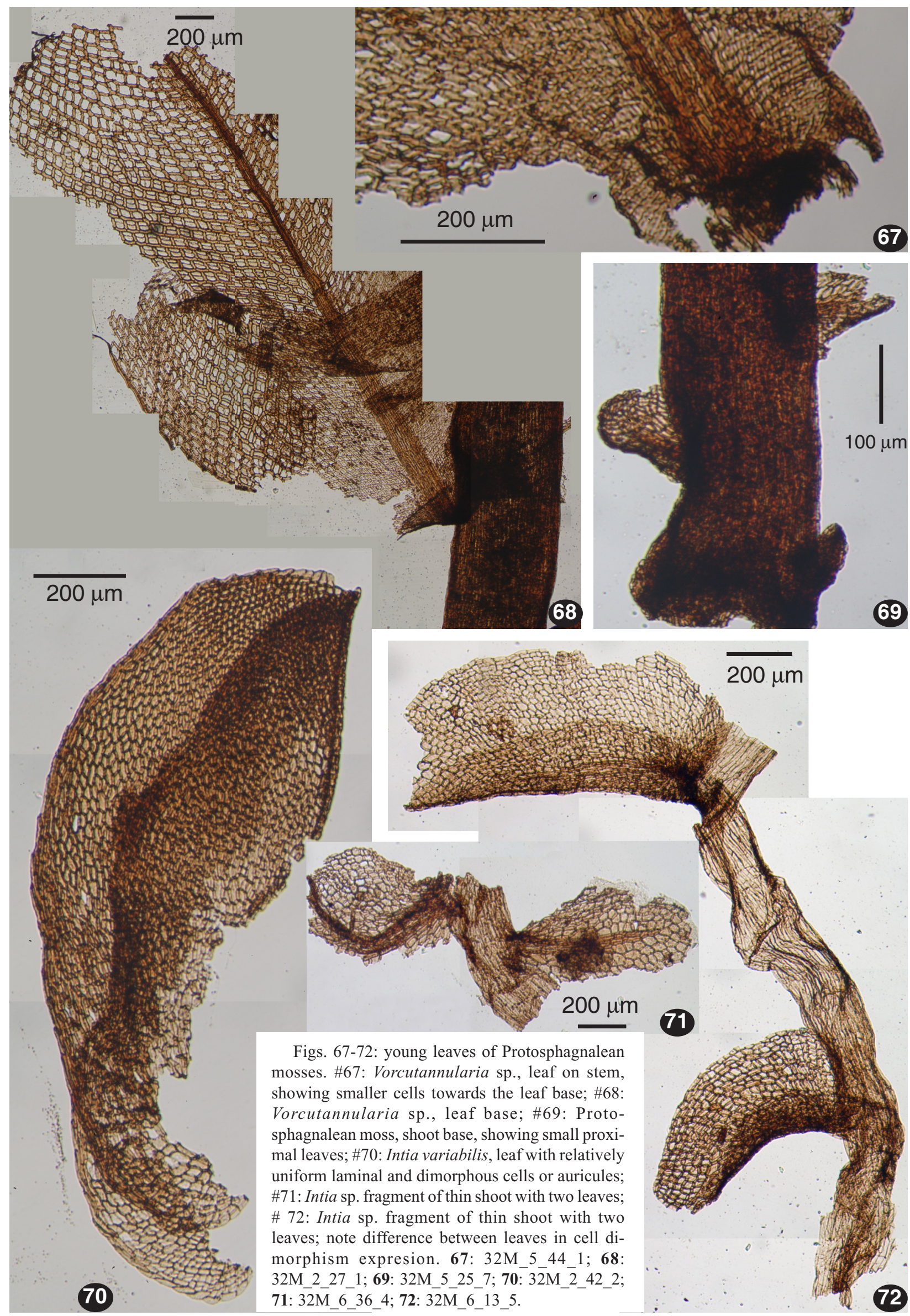



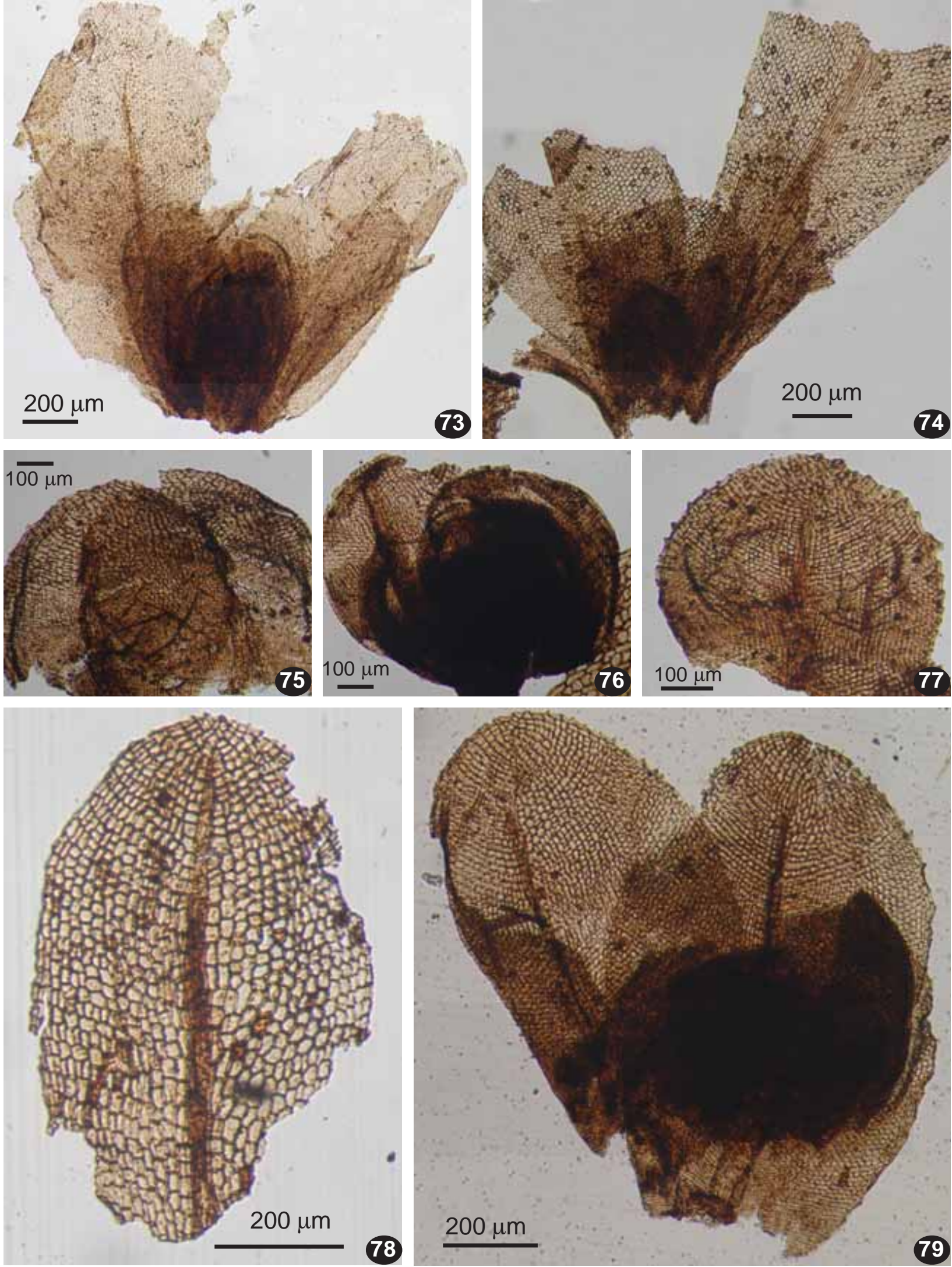

Figs. 73-79: Young and/or partly undedeveloped leaves of Protosphagnalean mosses . \#73: Protosphagnum nervatum, crowded leaves at shoot end; \#74: Intia angustifolia, crowded leaves at shoot end; \#75-77: I. variabilis (?), crowded young leaves (unclear if from shoot end or lateral innovation); \#78: Kosjunia sp. (?), small leaf showing arching cell rows in mid-leaves; 79: Intia variabilis (?): yound leaves, note extensive area of small cells in right leaf. 73: 32M_6_44_12; 74: 32M_2_33_3; 75: 32M_5_34_2; 76: 32M_5_34_7; 77: 32M_5_30_2; 78: 32M_6_6_5; 79: 32M_2_27_2. 


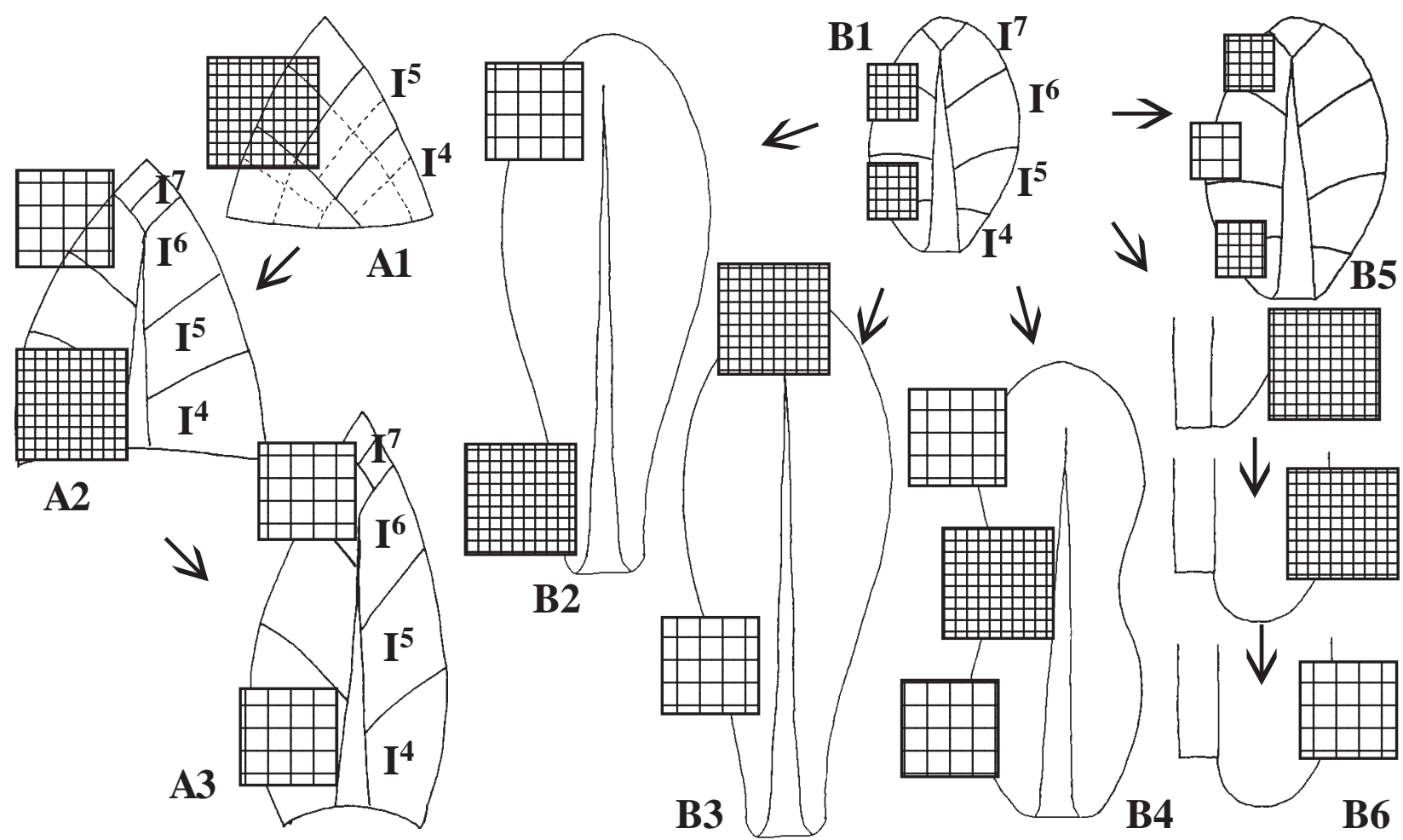

Fig. 80. Scheme of leaf development in modern Bryopsida (A) and hypothetical scheme for Protosphagnales (B), showing various aspects in delay of differentiation. Zones with small, undifferentiated cells and larger, developed cells are shown by dense and loose hatching. $\mathrm{I}^{4}-\mathrm{I}^{7}$ denote sectors formed by consequentional divisions of leaf apical cells (cf. Frey, 1971). The earliest stage of leaf development in Protosphagnales in unclear and not shown; B1 can be comapred to Figs. 76-77 and Fig. 48, although both are slightly later than B1; B2-B5 shows still undifferentiated leaves, as the fully differentiated are characterized by the absence of small cells. B2 represents the case of e.g. Vorcutannularia (Figs. 65, 68), similar ot A2; B3 is best seen in Intia angustifolia, Figs. 6,8, 13; B4 can be examplified by Figs. 33, 35, 39; B5 occurs in e.g. Junjagia glottophylla, Fig. 49; B6 shows differentiation in auricules, cf. Figs. 59-60.

Developing after certain delay, alar cells of the narrow base are not limited by tension from decurrencies and can freely grow into extensive auricles. Plausible stages of their development can be approximately presented in a series by Figs. 53-60-59-2B and cf. Fig. 80: B6.

Differentiation in developed auricles can be of two types. Auricles in Protosphagnum are composed totally of dimorphic cells (Fig. 2B), like the main part of leaf, however, dimorphic cells in auricules can be observed in leaves with otherwise uniform cells (Fig. 70). The tendency to more expressed cell dimorphism in a proximal part of leaf was discussed by Ignatov (1990), and here this general rule can be confirmed.

Another way of cell dimorphism near the leaf base has been described by Neuburg (1960: Tables 67-2 and 68-3) for Vorcutannularia, where a net of narrower (and sometimes darker) cells, with paler cells within large and irregular loops, appears. This pattern of areolation can be seen in Fig. 54, 56, in a putative Intia specimen, although not so apparent as in Neuburg' material.

The simultaneous presence of small cells in basal and median parts of leaf is rarely observed (Fig. 50), for example in Kosjunia, where small cells can be seen at base and in the median part of leaf, shortly below the subapical zone.
Summing up this rather scattered and fragmentary observations, the following scenario can be suggested for the leaf development in Protosphagnalean mosses (Fig. 80B).

Contrary to modern mosses (Fig. 80A), the leaf sectors, $I^{4}, I^{5}, I^{6}$, using terminology of Frey (1971), seem to be relatively independent, and the most basal of them, $\mathrm{I}^{4}$, is likely not the largest one as it is the case in most modern mosses. The 'independence' in this context means that the cell maturation in leaf sectors is not sequentially basipetal, as in most of modern mosses (Fig. 80B).

Due to this independence:

1) Cell divisions may continue in subapical part already after the main part of lamina has developed (Figs. 5, 8, 13 and compare Fig. 80-B3).

2) Small cells in mid-leaf could differentiate both acropetally and basipetally (Figs. 32-36 \& 39/Fig.80: B4).

3) Differentiation above a zone of small cells in the median part of leaf could result in a stronger cell dimorphism in an upper leaf, whereas in other cases, e.g. in Intia and Protosphagnum, cell dimorphism is stronger expressed in a basal leaf portion (Figs. 70 \& 72; also Fefilova, 1978, Ignatov, 1990).

4) The pattern of cell dimorphism is strongly related to the shift of cell rows during the leaf development, and 
in upper part (where the leaf is getting broader) dimorphism is more pronounced.

5) Late development of small $\mathrm{I}^{4}$ sector allows late growth of auricules, being not limited by decurrencies which are almost absent.

It remains an open question how broad variation in cell development was within each species, because the present material obviously represents a mixture of several genera, and discussing them altogether may look confusing.

However, the areas of small cells have been found: (1)in the upper part of leaf in Intia, Junjagia and Protosphagnum; (2) in the median part in Intia, Junjagia, Kosjunia, and Vorcutannularia, and (3) in the basal part in Intia, Junjagia, Kosjunia, and Vorcutannularia. Thus, together with other characters of the order Protosphagnales given in the introductory section, these patterns in arrangement of zones of small cells should be considered as a common characters of this Palaeozoic moss order.

\section{ACKNOWLEDGEMENT}

We are grateful to A. Vlasov for considerable help in finding moss-bearing deposits in the field, to A. Ivanova for correcting English of the manuscript. The work was partly supported by RFBR 10-04-00678 \& 12-04-32195.

\section{LITERATURE CITED}

[ABRAMOV, I.I. \& L.I. SAVICZ-LYUBITSKAYA] АБРАМОВ, И.И. \& Л.И САВИЧ-ЛЮБИЦКАЯ 1963. Отдел Bryopsida. - [Division Bryopsida].В кн.: Орлов Ю.А. (ред.) Основы палеонтологии, том "Водоросли, мхи, псилофиты, плауновые, членистостебельные, папоротники. М., Госгеолтехиздат [In Osnovy paleontologii, Volume "Vodorosli, mkhi, psilofity, plaunovye, chlenistostebelnye, paporotniki" (Ed Yu. A. Orlov), Gosgeoltekhizdat, Moscow]: 344-414.

ANDREWS, H.N. Jn. 1961. Studies in paleobotany. - New York \& London: John Wiley \& Sons, $487 \mathrm{pp}$.

DARRAH, W.C. 1960. Principles of palaeobotany. - New York: Ronald Press Cp., VII+295 pp

[DONSKOV, D.G.] ДОНСКОВ Д.Г. 2012. Реконструкция морфогенеза листа мхов и его связи с формой листа и особенностями биологии видов. - [Retrospective restoration of moss leaf morphogenesis and its relation to leaf shape and species biology] Aвтореф. канд. бил. наук. М., ГБС РАН [Abstract of PhD. Thesis, Moscow GBS RAN], $23 \mathrm{pp}$.

[FEFILOVA, L.A.] ФЕФИЛОВА Л.А. 1978. Листостебельные мхи перми Европейского Севера СССР. - [Permian mosses of European North of USSR] Л., Наука [Leningrad, Nauka],120 pp.

FRAHM, J.P. 2010.Die Laubmossflora des Baltischen Bernsteinwaldes. - Jena, Weissdorn Verlag. 101 pp.

FREY W. 1970 [1971]. Blattentwicklung bei Laubmoosen. - Nova Hedwigia 20: 463-556.

[GOMANKOV, A. V. \& S. V. MEYEN] ГОМАНКОВ, А.В., С.В.МЕЙЕН 1987. Татариновая флора (состав и распространение в поздней перми Евразии). - [Tatarina flora (composition and distribution in the Late Permian of Eurasia)] Труды геол. ин-та АН СССР [Trudy Geol. Inst. Akad.Nauk SSSR] 401: 1-174.

[IGNATIEV, I.A. \& D.A. IGNATIEV] ИГНАТЬЕВ И.А., Д.А.ИГНАТЬЕВ 2001. Эволюция растительности и условия осадконакопления в поздней перми котловины Большая Сыня Предуральского прогиба. - [Evolution of the vegetation and of the conditions of sedimentation in the Late Permian of Bolshaia Synia depression of the Uralian Foredeep] Материалы симпозиума памяти Сергея Викторовича Мейена (1935-1987), Москва, 25-26 декабря 2000. M. ГEOC [Transactions of the Symposium, dedicated to the memory of Sergei Viktorovich Meyen (1935-1987). Moscow, December 25-26, 2000. M: GEOS]: 178-186.

IGNATOV, M. S. 1990 Upper Permian mosses from the Russian Platform. - Palaeontographica Abt. B, 217: 147-189 + Pl. 1-9.

IGNATOV, M.S. 1992. Bryokhutuliinia jurassica, gen. et spec. nova, a remarkable fossil moss from Mongolia. - J. Hattori Bot. Lab. 71: 377 388 .

IGNATOV, M.S. \& E.E. PERKOVSKY 2011. Mosses from Rovno amber (Ukraine). - Arctoa 20: 1-18.

IGNATOV, M.S. \& D.E. SHCHERBAKOV 2007. Did pleurocarpous mosses originate before the Cretaceous? - In: Newton, A.E. \& R. Tangney (eds.) Pleurocarpous mosses: systematics and evolution. [Syst. Ass. Special Vol. 71)] CRC Press, Boca Raton-London-New York: 321-336.

IGNATOV, M.S. \& D.E. SHCHERBAKOV 2009. A new fossil moss from the Lower Permian of the Russian Far East. - Arctoa 18: 201-212.

IVANOV, O.V. \& M.S. IGNATOV 2013. 2D Digitization of plant cell areolation by polarized light microscopy. - Cell and Tissue Biology 7(1): 103-112. / ИВАНОВ, О.В., М.С. ИГНАТОВ 2012. Двухмерное цифровое представление клеточной сети растений с помощью оптической поляризационной микроскопии. - Цитология 54(11): 862-869.

KRASSILOV, V.A. 1973. Mesozoic bryophytes from the Bureja Basin, Far East of the USSR. - Palaeontographica, Abt. B, 143: 95-105 + Pl. 41-51.

LORENZ, P.G. 1864. Studien über Bau und Entwicklungsgeschichte der Laumboose. - In: Lorentz, P.G. (ed.) Moosstudien. Leipzig, Verlag W.Engelmann. 1-36+4 Tabs.

MENNING M., A.S. ALEKSEEV, B.I. CHUVASHOV, V.I. DAVYDOV, F.-X. DEVUYST, H.C. FORKE, T.A. GRUNT, L. HANCE, P.H. HECKEL, N.G. IZOKH, Y.-G. JIN, P.J. JONES, G.V. KOTLYAR, H.W. KOZUR, T.I. NEMYROWSKA, J.W. SCHNEIDER, X.-D. WANG, K. WEDDIGE, D. WEYER \& D.M. WORK 2006. Global time scale and regional stratigraphic reference scales of Central and West Europe, East Europe, Tethys, South China, and North America as used in the Devonian-Carboniferous-Permian Correlation Chart 2003 (DCP 2003). -Palaeogeogr., Palaeocliatol., Palaeoecol. 240: 318-372.

MEYEN, S.V. 1982. The Carboniferous and Permian floras of Angaraland (a synthesis). - Biol. Mem. 7: 1-110.

MILLER, N.G. 1983.Tertiary and Quanternary fossils. - In: Schuster, R.M. (ed.), New manual of bryology, vol. 2, Nichinan, Hattori Botanical Laboratory: 1194-1237.

MÜLLER, C. (BEROL) 1898. Musci (Laubmoose). Fortpflanzungsverhältnisse und Entwiklungsgeschichte. - In Engler, A. \& K. Prantl (eds.) Die Natürlichen Pflanzenfamilien. Leipzig, Verlag W.Engelmann 1(3): 155-202.

[NEUBURG, M.F.] НЕЙБУРГ М.Ф. 1960. Листостебельные мхи из пермских отложений Ангариды. - [Mosses from the Permian of Angaraland] Труды ГИН АН СССР [Trudy Geologicheskogo Instituta Akademii Nauk SSSR] 19: 1-104 + 78 pl.

[PUKHONTO, S.K.] ПУХOНTO С.К. 1998. Пермская стратиграфия и флора угольных отложений Печерского бассейна. - [Permian stratigraphy and flora of coal deposits of the Pechora Basin]. M., Научный Мир [Moscow, Nauchny Mir], 312 pp.

WU, X.-W., X.-Y. WU \& Y.-D. WANG 2000. Two new forms of Bryiidae (Musci) from the Jurassic of Junggar Basin in Xinjiang, China. - Acta Palaeontol. Sinica 39, Suppl: 167-175. 